\title{
1 Urbanization plays a minor role in the 2 flooding and surface water chemistry of 3 Puerto Rico's mangroves
}

\author{
4 Benjamin L. Branoff \\ 6 Department of Biology \\ 7 University of Puerto Rico-Río Piedras \\ 8 San Juan, Puerto Rico, 00931, U.S.A \\ benjamin.branoff@gmail.com \\ ORCID 0000-0002-8796-2039 \\ 12 phone: $386-506-7997$ \\ 13 fax: $787-764-2610$

\section{ACKNOWLEDGEMENTS}

5

14

15

16

Research was partly funded by the United States Forest Service International Institute of 20 Tropical Forestry, San Juan, Puerto Rico. Ariel Lugo, Ferdinand Quiñones, and Autumn Oczkowski provided feedback on first drafts. 


\section{ABSTRACT}

2 Although hydrology and water chemistry are known to change in proximity to cities, there

3 remains little empirical evidence connecting specific components of urban landscapes to

4 mangrove flooding dynamics or surface water chemistry. This study constructs five-year water

5 level models from tidal harmonics and precipitation inputs to characterize mangrove flooding

6 across urban gradients in three watersheds of Puerto Rico. There was some evidence for an

7 influence of urbanization on both flooding and water chemistry, but this depended on the

8 definition of urbanness, and points instead to geomorphology as the primary culprit. Urban sites

9 exhibited $46 \%$ longer hydroperiods and $450 \%$ lower depths than non-urban sites. Rainfall

10 importance was explained more by geomorphology than by urbanization and suggested systems

11 with limited tidal connectivity are four times more sensitive to rainfall than systems with full

12 tidal connectivity. There was also evidence for changes in tidal amplitudes along the urban

13 gradient, which may explain the observed differences in flooding. Relationships between surface

14 water chemical metrics and land cover contradicted previous studies by suggesting lower

15 nutrients and biochemical oxygen demand with increasing urbanization. These results reinforce

16 the understanding that the most important drivers of urban mangrove hydrology and water

17 quality in Puerto Rico are likely geomorphology and tidal connectivity, with little but not zero

18 influence from surrounding land cover. Results should be considered alongside the reported

19 errors stemming from inaccuracies in digital elevation and rainfall response models, and will be

20 useful in understanding future ecological censuses on the island.

\section{Keywords:}

22 Urban mangroves; Anthropocene; novel ecosystems; storm water; tidal harmonics 


\section{INTRODUCTION}

As forested tidal wetlands along primarily tropical and subtropical coastlines, mangroves

3 are often under pressure from urban development and the subsequent effects on surface water

4 chemistry and hydrology, both of which play important roles in ecosystem function and the

5 provisioning of services (Lugo and Snedaker 1974; Wolanski et al. 1993; Ewel et al. 1998;

6 Medina 1999; Bosire et al. 2008; Lee et al. 2014). Specifically, metrics of flooding frequency,

7 duration, and depth have been singled out as most important in influencing mangrove physiology

8 and zonation (Krauss et al. 2006; Bosire et al. 2008; Lugo and Medina 2014). Likewise,

9 concentrations of nitrogen and phosphorus as well as salinity and temperature have also been

10 shown to be important indicators of mangrove nutrition, stress, and function (Medina 1999;

11 Feller et al. 2003; Lovelock et al. 2009). Tides and rainfall contribute to system hydrology and

12 water chemistry (Twilley and Chen 1998; Sutula et al. 2001), but groundwater, fluvial, and

13 anthropogenic contributions may also be important in some systems (Ellison and Farnsworth

14 1996; Lee et al. 2006; Sakho et al. 2011; Gleeson et al. 2013). Thus, variations in

15 geomorphology, which influence the breadth of the above hydrological contributions, is another

16 important consideration when assessing mangrove ecosystems (Kjerfve et al. 1999; Adame et al.

17 2010). The complexity of this suite of potential influences is likely exacerbated in highly urban

18 systems, where surface water flow and chemistry are directly and indirectly altered through

19 impervious surfaces, infrastructure, and engineering projects (Leopold 1968; Hollis 1975;

20 McClelland and Valiela 1998; Lee et al. 2006; Dietz and Clausen 2008). Although urban

21 mangrove hydrology has been shown to be abnormal in some cases, few studies identify or

22 quantify the specific influence of urbanization on hydrology or surface water chemistry. 

directly or indirectly a result of changes to hydrology and sedimentation, which vary spatially and temporally in intensity. This is corroborated for forested wetlands in general (Faulkner

4 2004), but mangroves are unique in their tidal connectivity and specific examples from urban systems are scarce. The influence of municipal sewage discharge on mangroves has been well documented and generally leads to nutrient enrichment, heavy metal contamination, and sometimes mortality (Clough et al. 1983; Mandura 1997; Wong et al. 1997; Branoff 2017). Further, a number of studies point to changes in mangrove coverage following large engineering projects that alter surrounding geomorphology, but these are not necessarily related to urbanization, or use qualitative or otherwise ambiguous definitions of "urban" (Colonnello and Medina 1998; Tian-Hong et al. 2008; Sakho et al. 2011; Marois and Mitsch 2017). Studies directly linking quantified variations in urbanization metrics, such as impervious surface coverage, population density, or forested area, with changes in mangrove flooding dynamics or surface water chemistry are absent from the literature.

17 direct ties between the relative intensity of urbanization and changes in flooding metrics or surface water chemistry. The geomorphology of the San Juan Bay Estuary has been modified through canalization or dredging or both over the course of the city’s 500 year history (Ellis

20 1976; Cerco et al. 2003). This has resulted in changes in underlying aquifer levels and salinities,

21 as well as surface water chemistry and connectivity that are often associated with risks to both

22 human and ecological health (Seguinot Barbosa 1996; Bunch et al. 2000). Large-scale

23 engineering projects have since been proposed to mitigate these issues (Cerco et al. 2003), and 
1 are currently in various phases of implementation. However, apart from sewage discharge, there

2 has been no reported effort to understand how specific components of the urban landscape (e.g.

3 impervious surfaces, roads, population density) may be influencing mangrove flooding metrics

4 or surface water chemistry. This holds true for the various other coastal urban watersheds of

5 Puerto Rico, where mangroves have endured a long history of anthropogenic influences

6 (Martinuzzi et al. 2009).

This study aims to characterize and model surface water fluctuations in the mangroves of

8 three watersheds in Puerto Rico, using both long and short-term water level recordings, as well

9 as rainfall and tidal harmonics models. It then uses these models alongside digital elevation

10 models to analyze the flooding dynamics of the mangroves and correlates these, as well as

11 surface water chemical properties, with surrounding land cover along gradients of urbanization.

12 Specifically, this study tests the hypothesis that increasing surrounding urbanization is associated

13 with variations in mangrove flooding and surface water chemistry. These connections must be

14 well-understood for successful mangrove management (Lewis 2005; Bosire et al. 2008), and will

15 be important in understanding the influence of urban land cover on mangrove ecology, especially in the context of future floral and faunal censuses in the study areas.

\section{METHODOLOGY}

Three watersheds in Puerto Rico were selected based on the range in urbanization surrounding their mangroves. This was calculated as described below using spatial datasets of urban, open water, and vegetation classifications, as well as mangrove extent, population density

21 and road lengths. These were combined as an urban index value to give a single relative

22 representation of urbanization for one hundred random mangrove locations in all watersheds of 
1 Puerto Rico (Figure 1a \& 1b). Sites were then selected within three watersheds to give the greatest possible range in urbanization within the mangroves (Figure 1c).

\section{Study Locations}

Three watersheds were chosen because their mangroves held the greatest range of urbanization. They are the San Juan Bay Estuary, the Río Inabón to the Río Loco (Ponce), and

7 the Río la Plata (Levittown) (Figure 1a). The San Juan Bay estuary was divided into ten separate mangrove regions, and Ponce and Levittown into three regions each. This resulted in sixteen

9 study locations throughout the three watersheds.

The San Juan metropolitan area lies within the watershed described as between the Río

11 Grande de Loíza and the Río Bayamon. The $240 \mathrm{~km}^{2}$ drainage basin encompasses $25 \mathrm{~km}^{2}$ of

12 open water, consisting of five embayments connected by a system of natural and canalized

13 channels (Bunch et al. 2000). The estuary is home to the island's largest and densest human

14 population, 0.5 million people and 1,800 people $/ \mathrm{km}^{2}$ in the municipalities of San Juan, Carolina

15 and Bayamón (United States Census Bureau 2016). Given the intense human presence around

16 the estuary, a number of studies have described its hydrodynamic and contamination issues,

17 which range from eutrophication and heavy metals to tidal flushing and connectivity (Webb and

18 Gómez-Gómez 1998; Bunch et al. 2000; Cerco et al. 2003; Acevedo-Figueroa et al. 2006). The

19 estuary also harbors the islands largest mangrove forest, Bosque Estatal de Piñones, which at

202,550 ha represents roughly $11 \%$ of the watershed area (Brandeis et al. 2014). The combination

21 of intense urbanization and expansive forested and open water areas within this watershed results 

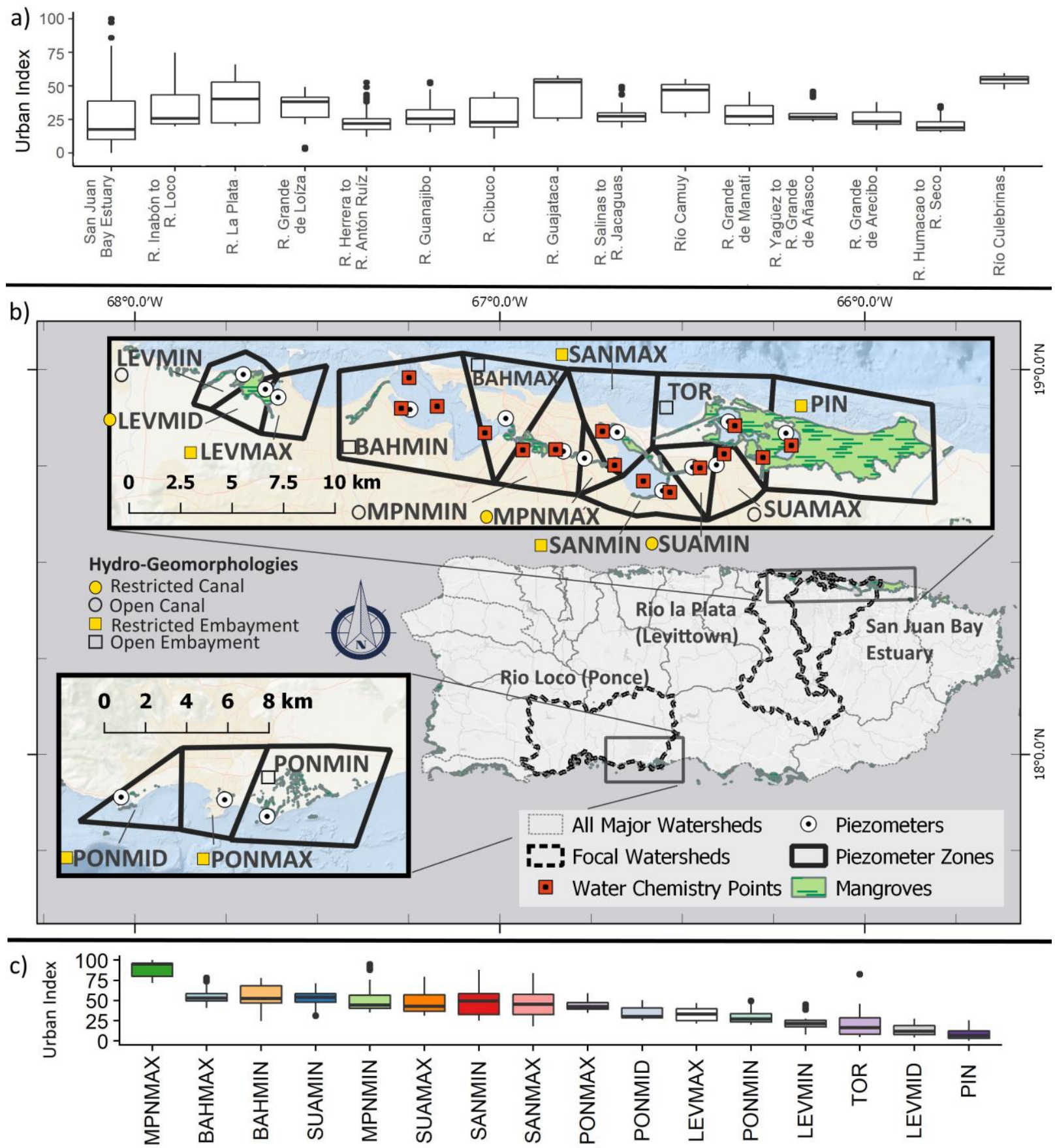

Figure 1 Study sites were selected by first choosing the three watersheds with the greatest range in urban index (a, ordered form left to right in decreasing urbanization range). The urban index is a combination of urban land use, vegetation and open water coverage, population density, and road length. Piezometers were placed within these watersheds (b), resulting in a gradient of urbanization across all sites (c). Inlay polygons represent individual piezometer zones. Water chemistry measurements were only available for the San Juan Bay Estuary. "MAX" and "MIN" postscripts refer to urbanization levels within each zone. BAH is the San Juan Bay, MPN is the Caño Martín Peña, SAN is the San José lagoon, SUA is the Suarez canal, TOR is the Torrecillas lagoon, $\mathrm{PIN}$ is the Piñones lagoon, LEV is Levittown and PON is Ponce 
1 in the greatest range in mangrove urbanization on the island. The median annual rainfall for this

2 site was $1,463 \mathrm{~mm}$ from 2012 to 2017 (this study). proposed (Ellis 1976; Seguinot-Barbosa 1983; United States Army Corps of Engineers 2015).

5 Previous dredging has taken place in the San Juan Bay, and the Condado, San Jose and

6 Torrecillas lagoons from the 1950s to the 1970s (Ellis 1976). These projects increased lagoon volumes and flow rates through canals, and decreased surface areas where dredging material was

8 placed along shorelines. It is expected that this has resulted in lower residence times for sewage

9 effluents and storm-water discharge, but greater prevalence of anaerobic zones. The estuary is composed of an artificial tidal lagoon constructed to drain surrounding settlements and connected to the ocean through a tidal creek and permanent inlet. Little is reported on these mangroves, although the estuary has been the focus of flood mitigation efforts for surrounding neighborhoods (USACE 1987). One informal water quality survey suggested elevated sewage input as evident in high fecal coliform loads and high nutrient concentrations, as well as minimal

17 tidal connectivity and the temporary influence of precipitation on water levels and salinity (USGS 2011). Levittown median annual rainfall from 2012 to 2017 was 1752 mm (this study). The island's second largest metropolitan area is Ponce, which falls within the watershed described as lying between the Río Inabón and the Río Loco on the southern Caribbean coast.

21 Unlike the other two watersheds, the mangrove sites at Ponce are largely unconnected and do not

22 share the same estuarine conditions. The three mangrove forests within this study were located at 23 Punta Cabullones, the Rafael Cordero Santiago Port of the Americas, and on the northern shore 
1 of Laguna de Salinas at Punta Cucharas. One study has covered the hydrology and water quality of some of these mangroves (Rodríguez-Martínez and Soler-López 2014), which found dissolved oxygen, specific conductance, and salinity to be dependent upon seasonal changes in hydrologic inputs during the wet and dry seasons. The site received a median annual rainfall of $755 \mathrm{~mm}$ from 2012 to 2017 (this study).

Based on aerial imagery and previously mentioned hydrological studies, sites have been classified into hydrogeomorphic settings of embayments (i.e. ocean, bay, or lagoon) or canals, and either open or partially restricted to tidal exchange (Figure 1b). Ocean and bay sites by their nature have direct tidal exchange and are thus always classified as open. These sites are the two San Juan Bay sites BAHMIN and BAHMAX, and the ocean site in Ponce, PONMIN. Lagoon or canal sites may have open or partial tidal exchange. Torrecillas lagoon is an open lagoon due to its dredged mouth at boca de cangrejos (Ellis 1976). Open canals are the east end of Suárez canal, SUAMAX, which shares the dredged connection with Torrecillas, the west and dredged portion of the Caño Martin Peña, MPNMIN, and the mouth of the Rio Cocal in Levittown, LEVMIN. In contrast, partially restricted canals are that connecting the Rio Cocal to the Levittown lakes, LEVMID, and the undredged eastern portion of the Caño Martín Peña, MPNMAX. Partially restricted embayments are those of Piñones (PIN) and San José (SANMIN and SANMAX) in the San Juan Bay Estuary, Levittown lakes (LEVMAX) in Levittown, and the Salinas lagoon (PONMID) and the Port of the Americas in Ponce (PONMAX).

\section{Calculating Urbanization}

Spatial datasets used for the selection of study sites and the calculation of urban variables are described in Table 1. All spatial analyses were performed in the R programming language (Yan et al. 2011). Individual functions in $\mathrm{R}$ are stated along with their corresponding packages 
Table 1 Spatial datasets used to determine relative elevations and to quantify the urbanization surrounding each study site. Variables were sampled from a sampling area described by a circle of radius $500 \mathrm{~m}$ and centered on individual study sites.

\begin{tabular}{|c|c|c|}
\hline Variable & Dataset Description & Source \\
\hline $\begin{array}{l}\text { Land Cover } \\
\text { Urban } \\
\text { Vegetation and Water }\end{array}$ & $\begin{array}{l}2 \mathrm{~m} \text { resolution land cover } \\
\text { raster for Puerto Rico in } 2010\end{array}$ & $\begin{array}{l}\text { (Office for Coastal } \\
\text { Management 2017) }\end{array}$ \\
\hline Mangrove Coverage & $\begin{array}{l}30 \mathrm{~m} \text { resolution continuous } \\
\text { mangrove coverage raster for } \\
2012\end{array}$ & (Hamilton and Casey 2016) \\
\hline Population Density & $\begin{array}{l}\text { Total population shapefile for } \\
2010 \text { in Puerto Rico by census } \\
\text { block }\end{array}$ & (U.S. Census Bureau 2010) \\
\hline Road Length & $\begin{array}{l}\text { Road network shapefile for } \\
\text { Puerto Rico in } 2015\end{array}$ & (U.S. Census Bureau 2015) \\
\hline Elevation & $\begin{array}{l}\text { Digital elevation models for } \\
\text { sites, at } 3 \& 1 \mathrm{~m} \text { horizontal } \\
\text { resolution and } 9 \text { and } 4.2 \mathrm{~cm} \\
\text { vertical accuracy for the } \\
\text { northern and southern sites, } \\
\text { respectively }\end{array}$ & (NOAA 2015a, b) \\
\hline
\end{tabular}

1 and authors. For brevity, these are reported as package::function, following the notation in the R

2 language. Packages used in these analyses include sp (Bivand et al. 2013), rgeos (Bivand and

3 Rundel 2017), and raster (Hijmans 2016). Commented subroutines for these analyses are

4 provided at github.com/BBranoff/Urban-Mangrove-Hydrology, and a schematic outlining the

5 process is demonstrated in Figure 2.

To begin, one hundred random points were placed within mangrove classified habitat in each watershed of Puerto Rico (NOAA Biogeography Program 2011). To assess the surrounding land coverage, a sampling circle of radius $500 \mathrm{~m}$ was created around each point, and mangrove coverage and land cover datasets were then cropped and masked to include only those cells within the circle. The total mangrove coverage for each point was then calculated by summing each class, in which urban was classes 2 and 5 (Impervious and Developed Open Space, 


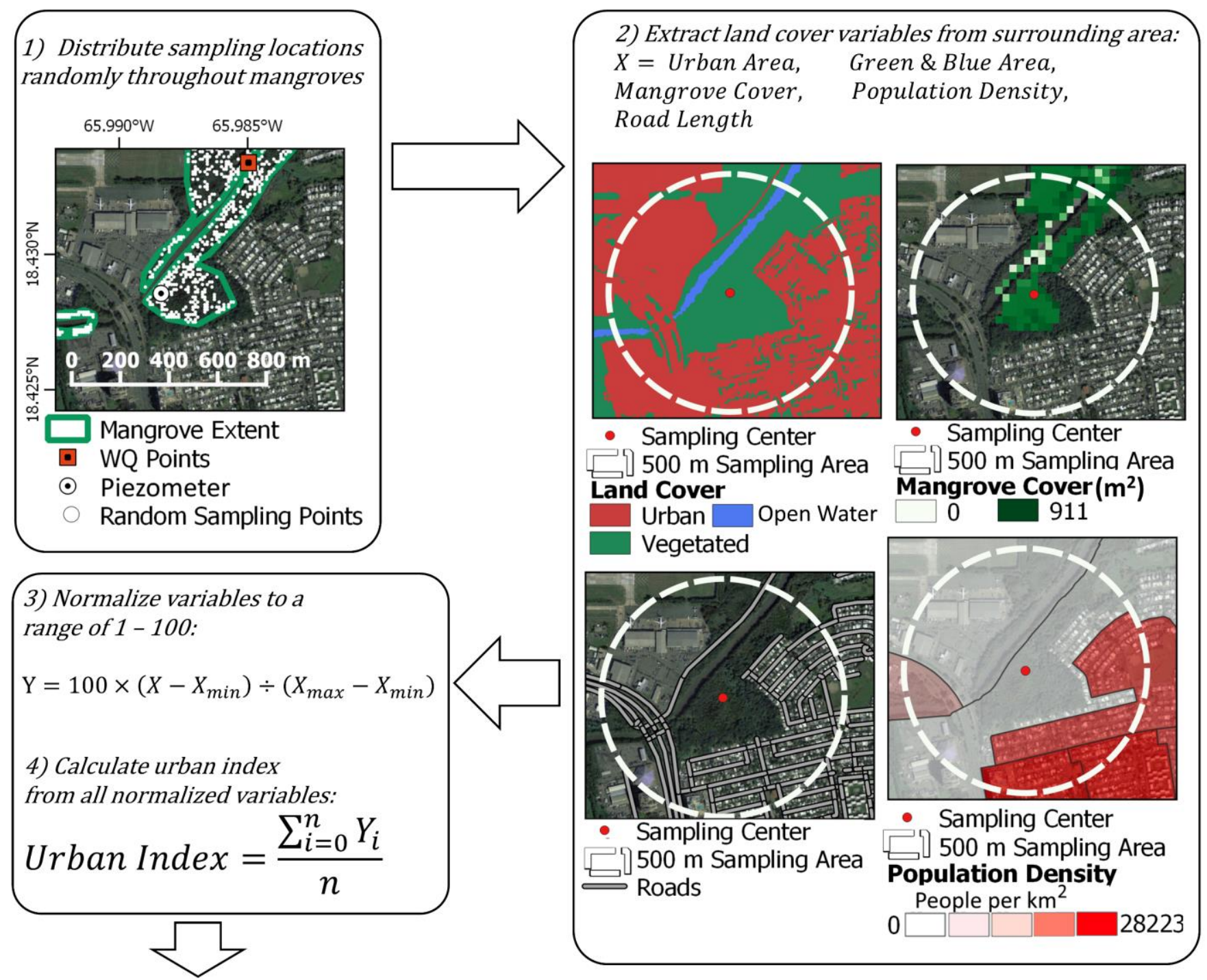

5) Sample elevation of piezometer and mangrove location

6) Calculate water levels at random sampling point

Water level at
sampling point $=\begin{aligned} & \text { elevation of piezometer }+ \\ & \text { water level at piezometer }- \\ & \text { elevation of sampling point }\end{aligned}$

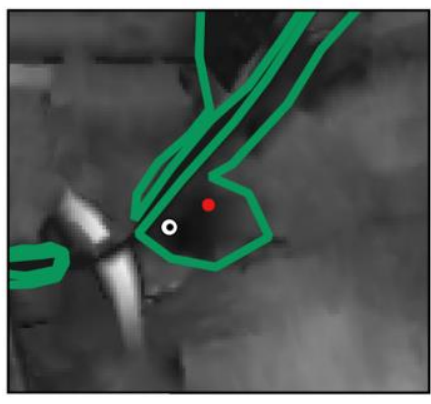

Mangrove Extent

- Sampling Point

Elevation (m)

$\odot$ Piezometer

$\square-1 \square 10$

Figure 2 A schematic of the spatial sampling routine for the calculation of the urban index and water levels at random mangrove locations throughout the study area. Sampling locations were distributed randomly throughout the mangrove habitat. Land cover within the surrounding 500 meters of these locations was then sampled and used to calculate the urban index. Elevations were sampled at each location and at the nearest piezometer, which were used to calculate the water levels at all locations. 
1 respectively), and green and blue area was the sum of all vegetation and open water classes,

2 defined as classes 6 through 18, and 21. These sums were then multiplied by the area of each

3 cell, which had a mean of $2.01 \mathrm{~m}$.

Road lengths within each circle were calculated by first clipping the entire road network

5 to include only the area within the circle and summing the combined length. Population density

6 within the sampling circle was calculated using 2010 US Census data at the block level. The total

7 population within the sampling circle was calculated assuming all people lived in non-road

8 impervious surfaces. The area of non-road impervious surfaces within each block was calculated

9 by first obtaining the total area of impervious surfaces through the methods of the previous

10 paragraph, using the boundary of each census block to sample the land cover within. This was

11 then used to calculate the population density per unit area of non-road impervious surfaces for

12 each block, which was then multiplied by the area of non-road impervious surfaces within each

13 part of each census block contained in the circular sampling area. This resulted in the total

14 number of people within the sampling area, which was then divided by the area of the circle to

15 give the population density.

These variables were used independently in further analyses, along with a combination of

17 all of them representing an urban index at each location. The index was calculated based upon a

18 similar method for aquatic ecosystems (McMahon and Cuffney 2000). The urban index value is

19 calculated using the following equation:

$$
\text { Urban Index }=\frac{\sum_{i=0}^{n} Y_{i}}{n}
$$

21 where $n$ is the number of variables used in the index, in this case the five variables of urban area,

22 green and blue area, mangrove area, populations density, and road length. $Y_{i}$ represents the 
1 variables normalized to a range of 0 to 100 through the following equation:

2

3

$$
Y=100 \times\left(X-X_{\min }\right) \div\left(X_{\max }-X_{\min }\right),
$$

In which $Y$ and $X$ represent the normalized and raw values, respectively. In the case of mangrove and blue-green coverage, the normalized variable was reversed by subtracting from 100 , so that lower values represent more urbanness. The urban index is thus a representation of the relative intensity of urbanization, in which 100 is the most urban site and 1 is the least urban site.

\section{Water Level and Weather Data Acquisition}

Water levels models were constructed from water level recordings made throughout the study area and from precipitation and barometric pressure observations from nearby weather stations. The models covered a five-year period, from June 1, 2012 to June 1, 2017. Data acquisition and subsequent modeling and statistical analyses were done in the $\mathrm{R}$ programming language (Yan et al. 2011). Individual functions with $\mathrm{R}$ are stated along with their corresponding packages and authors. For brevity, these are sometimes reported as package::function, following the notation in the R language. Additional utilized packages not mentioned below are the zoo (Zeilis and Grothendieck 2005), RJSONIO (Temple Lang 2014), and HyetosMinute packages (Kossieris et al. 2016).

\section{Water Levels}

Water levels were recorded in 16 locations within the three watersheds in Puerto Rico (Figure 1b). Piezometer wells were constructed from $2 \mathrm{~m}$ segments of 3" diameter PVC tubing. One half of the length of the well was perforated with $1 \mathrm{~mm} \times 1 \mathrm{~cm}$ slits placed every $1 \mathrm{~cm}$ using a sanding disc attached to a Dremel rotary tool. The wells were caped with PVC caps and one Onset HOBO U201 water level logger was hung from a $1.75 \mathrm{~m}$ cable attached to the top cap. 
1 Wells were placed in holes excavated at the shoreline using a 3" corer to a depth of $1.5 \mathrm{~m}$. The water level loggers were programmed to take pressure and temperature readings every 15 minutes. Data were extracted using an Onset HOBO waterproof shuttle at varying intervals averaging once every three months. Water levels were calculated from pressure readings using the HOBO barometric compensation tool in the HOBO Pro software and atmospheric pressure readings recorded at varying locations as described below.

\section{Weather Data}

Site precipitation and atmospheric pressure were acquired from varying sources as detailed in Table 2 and assembled into one-hour observations over the five-year period. Hourly observations were collected from wunderground.com using their Weather API feature (Table 2). For San Juan (SJU), this represented a complete set of observations, but the two other locations required additional data sources and approximations to compensate for large gaps in the wunderground data. Missing precipitation data were filled using daily values from the National Climate Data Center at various stations (Table 2). Hourly rainfall from these stations was reconstructed from the daily data through the DisagSimul function. Missing barometric pressure observations were approximated using a linear interpolation between known values calculated through the na.approx function.

\section{Surface Water Chemical Properties}

Surface water chemical properties were only available for the San Juan Bay Estuary, where most of the study sites are found. Measurements were downloaded from the San Juan Bay Estuary Program's water quality monitoring program. Monthly metrics were $\mathrm{pH}$, temperature $\left({ }^{\circ} \mathrm{C}\right)$, dissolved oxygen (DO) (mg/L), Salinity (PSS), and turbidity (NTU). Biannual metrics were 
Table 2 Weather data sources for the three regions included in the study (San Juan, Ponce, and Levittown, Puerto Rico). NCDC is the National Climate Data Center. Percent of observations are the percent of total rain observations for each watershed that were obtained from the corresponding sources.

\begin{tabular}{|c|c|c|c|c|}
\hline Data Type & Location & Station ID & Source & $\begin{array}{c}\text { Percent of } \\
\text { Observations }\end{array}$ \\
\hline $\begin{array}{l}\text { Hourly } \\
\text { Precipitation } \\
\text { \& Atmospheric } \\
\text { Pressure }\end{array}$ & $\begin{array}{l}\text { San Juan: } \\
18.4365^{\circ} \mathrm{N},-66.0069^{\circ} \mathrm{W}\end{array}$ & SJU & $\begin{array}{l}\text { Wunderground } \\
\text { weather station }\end{array}$ & $100 \%$ \\
\hline $\begin{array}{l}\text { Daily } \\
\text { Precipitation }\end{array}$ & $\begin{array}{l}\text { Levittown: } \\
18.4356^{\circ} \mathrm{N},-66.1678^{\circ} \mathrm{W}\end{array}$ & RQC00669415 & $\mathrm{NCDC}$ & $96 \%$ \\
\hline $\begin{array}{l}\text { Hourly } \\
\text { Precipitation\& } \\
\text { Atmospheric } \\
\text { Pressure }\end{array}$ & $\begin{array}{l}\text { Levittown: } \\
18.4422^{\circ} \mathrm{N},-66.1786^{\circ} \mathrm{W}\end{array}$ & ITOABAJA2 & $\begin{array}{l}\text { Wunderground } \\
\text { Personal } \\
\text { Weather } \\
\text { Station }\end{array}$ & $4 \%$ \\
\hline \multirow[t]{5}{*}{$\begin{array}{l}\text { Daily } \\
\text { Precipitation }\end{array}$} & $\begin{array}{l}\text { Ponce: } \\
18.0258^{\circ} \mathrm{N},-66.5252^{\circ} \mathrm{W}\end{array}$ & RQC00667292 & $\mathrm{NCDC}$ & $39 \%$ \\
\hline & $\begin{array}{l}\text { Ponce: } \\
18.0318^{\circ} \mathrm{N},-66.5996^{\circ} \mathrm{W}\end{array}$ & RQ1PRPC0002 & $\mathrm{NCDC}$ & $27 \%$ \\
\hline & $\begin{array}{l}\text { Ponce: } \\
18.0374^{\circ} \mathrm{N},-66.6017^{\circ} \mathrm{W}\end{array}$ & RQ1PRPC0005 & NCDC & $19 \%$ \\
\hline & $\begin{array}{l}\text { Ponce: } \\
18.0046^{\circ} \mathrm{N},-66.55891^{\circ} \mathrm{W}\end{array}$ & RQ1PRPC0001 & $\mathrm{NCDC}$ & $10 \%$ \\
\hline & $\begin{array}{l}\text { Ponce: } \\
18.0125^{\circ} \mathrm{N},-66.5874^{\circ} \mathrm{W}\end{array}$ & RQ1PRPC0006 & $\mathrm{NCDC}$ & $6 \%$ \\
\hline $\begin{array}{l}\text { Hourly } \\
\text { Precipitation } \\
\text { \& Atmospheric } \\
\text { Pressure }\end{array}$ & $\begin{array}{l}\text { Ponce: } \\
18.0086^{\circ} \mathrm{N},-66.5635^{\circ} \mathrm{W}\end{array}$ & TJPS & $\begin{array}{l}\text { Wunderground } \\
\text { weather station }\end{array}$ & $47 \%$ \\
\hline
\end{tabular}
total Kjeldahl nitrogen $(\mathrm{mg} / \mathrm{L})$, total nitrate and nitrite $(\mathrm{mg} / \mathrm{L})$, total phosphorous $(\mathrm{mg} / \mathrm{L})$, total organic carbon (TOC) (mg/L), ammonia (mg/L), biological oxygen demand (BOD) (mg/L), and

4 oil and grease (mg./L). The lowest detection limits and total number of samples for each metric

5 at each study site are included as Table 3. Although mangrove nutrition would be more

6 accurately represented by pore-water chemistry, there is a documented relationship between

7 surface and pore-water in mangrove systems (Bouillon et al. 2007; Gleeson et al. 2013), and also

8 between surface water chemistry and mangrove distribution (Sherman et al. 1998). Thus, these 
bioRxiv preprint doi: https://doi.org/10.1101/423434; this version posted September 21, 2018. The copyright holder for this preprint (which was not certified by peer review) is the author/funder, who has granted bioRxiv a license to display the preprint in perpetuity. It is made available under aCC-BY-ND 4.0 International license.

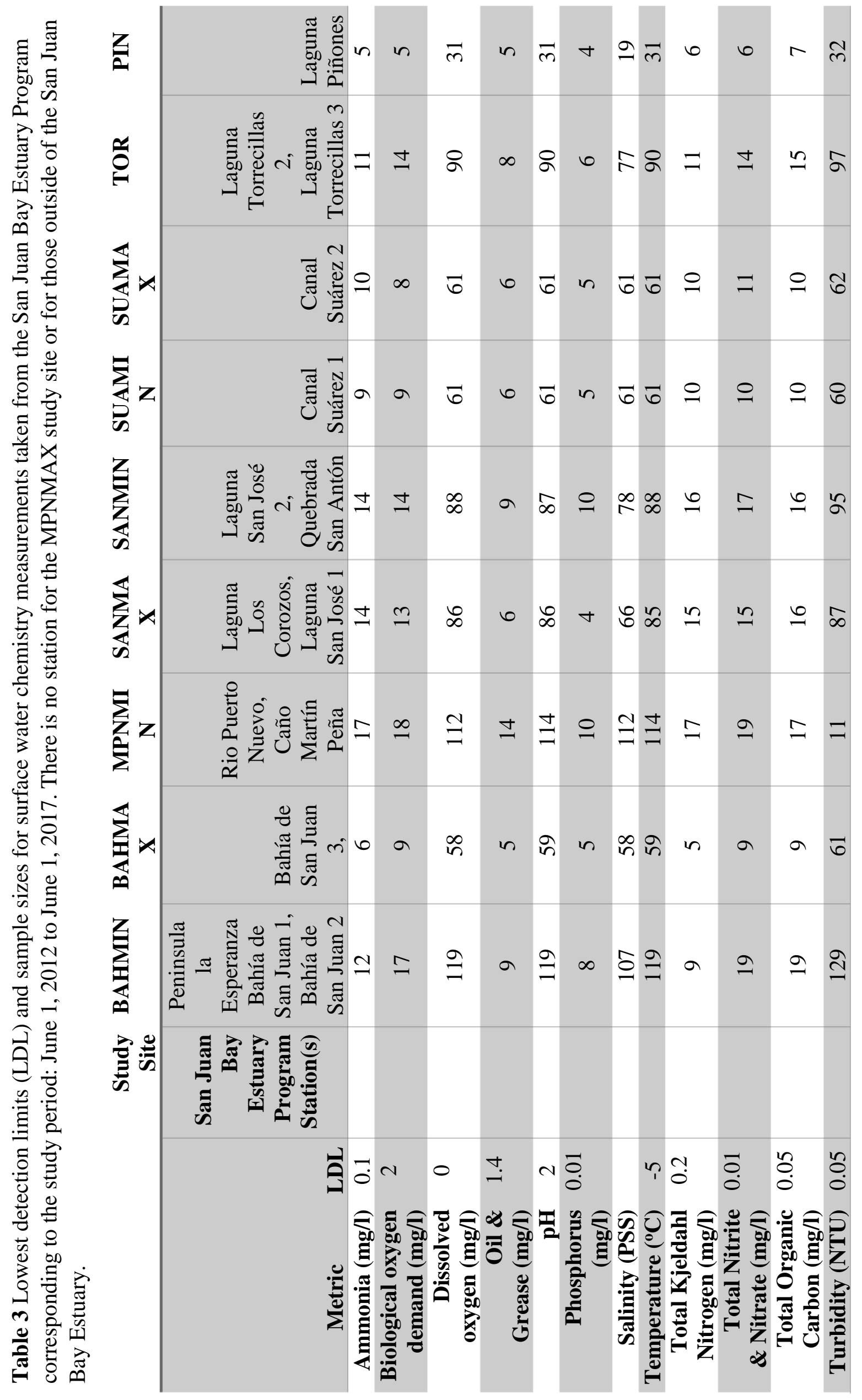


1 relatively easier to obtain surface water measurements will serve as a good indication of the

2 mangrove chemical environment over a large area.

\section{Modeling}

As with all other analyses, water level modeling was done in the R programming

5 language and a detailed, commented copy of the code can be found at

6 github.com/BBranoff/Urban-Mangrove-Hydrology. In addition to the packages mentioned

7 below, the TTR (Ulrich 2017), zoo (Zeilis and Grothendieck 2005), minqa (Bates et al. 2014),

8 and relaimpo packages (Grömping 2006) were also used throughout the process. Water levels at

9 each location were modeled using a combination of tidal and precipitation inputs. Tidal

10 components were modeled through the ftide function in the TideHarmonics package (Stephenson

11 2016), which uses timestamped water level observations to compute model coefficients for up to

12409 harmonic tidal constituents. Constituent amplitudes and phases interact to give a change in

13 water level, relative to the mean. Water levels due to tides at a given time, $\operatorname{Tides}(t)$, can thus be

14 modeled from all $N$ harmonic constituents by summing each individual $n$ constituent using the

15 following equation from Stephenson (2016):

$$
\operatorname{Tides}(t)=\sum_{n=1}^{N} f_{n} A_{n} \cos \left(\frac{\pi}{180}\left(\omega_{n} t+u_{n}+V_{n}-\psi_{n}\right)\right)
$$

17 The amplitude, angular frequency, equilibrium phase, phase lag, and nodal corrections for each constituent are given by $A_{n}, \omega_{n}, V_{n}, \psi_{n}, u_{n}$ and $f_{n}$ respectively. The time $(t)$ is represented as the

19 length, in minutes, from the origin of the model, which is dependent upon the period of observations at each site. Models were calculated for all observations in which the four-day

21 cumulative rainfall was less than $1 \mathrm{~mm}$ to avoid interference from precipitation inputs. The 
1 resulting coefficients of each tidal constituent were saved for further analyses and are given in

2 the Appendix A. These models were then used with the predict.tide function to predict water

3 levels every hour over the five-year period. The result is water level predictions based only on

4 tidal components.

Tidal predictions were then used along with rainfall data and the observed water levels to

6

7

8 compute contributions from precipitation. This contribution was modeled at each location through a combination of moving averages and moving sums, as has been implemented in other studies (Dawson and Wilby 1998; Toth et al. 2000; Altunkaynak 2007). Short-term response to rainfall was modeled with an exponential moving average (EMA) of precipitation. The shortterm contribution from precipitation is thus given as: rainfall data in the form:

In which min is the baseline water level, taken to be the minimum recorded observation, Rain is the observed precipitation in $\mathrm{mm}, n$ is the moving sum window, and $C$ is a dampening constant. Coefficients for both short and long term rainfall contributions were optimized for each location using a BOBYQA optimization, by minimizing the residual sum of squares between the observed water levels and the sum of the tidal and rain models (Powell 2009). 
predicted by combining the tidal and precipitation components through the equation:

$$
y(t)=\operatorname{Tides}(t)+\operatorname{RainEMA}(t)+\operatorname{RainMS}(t)
$$

In some cases, optimization resulted in zero contribution from tidal, or short and long-term piezometer, their relative importance of each in the overall model was also calculated. This was importance was calculated as the contribution of each constituent to the $\mathrm{R}^{2}$ of the full model against the observations (Lindeman 1980). This importance value was calculated for the ten tidal constituents with the greatest amplitude. The individual and cumulative $\mathrm{R}^{2}$ of all constituents in the water level models are reported in the results.

\section{Mangrove Elevations}

The above water level models were used to predict water levels throughout the mangroves in the three watersheds of the study. This was accomplished by assuming a planar, not curved water surface from tidal asymmetry (Wolanski et al. 1993). Thus, water levels at random points were calculated by subtracting their elevation from that of the observation piezometers and applying this adjustment to the predicted water levels (Figure 2). Mangroves were defined by a benthic habitat map of Puerto Rico (NOAA Biogeography Program 2011), and elevation was taken from two $3 \mathrm{~m}$ horizontal resolution coastal digital elevation models (DEM),

21 one for San Juan and Levittown (NOAA 2015a), and another for Ponce (NOAA 2015b). As with 
1 github.com/BBranoff/Urban-Mangrove-Hydrology. Additional packages utilized but not

2 mentioned below are deldir (Turner 2017), sp (Bivand et al. 2013), and raster (Hijmans 2016).

5 discrepancies between the benthic habitat map and the DEMs, resulting in extreme and likely

6 mistaken elevations assigned to mangrove habitat. To remove these extreme values, the

7 randomly sampled points were limited to elevations between the $10 \%$ and $90 \%$ quantiles. The

8 resulting elevations were subtracted from that at the piezometer location, and this adjustment was

9 added to the predicted water levels to give a time series of water levels at each point at every

10 hour within the five-year period.

\section{Calibration and Validation} were then validated by predicting water levels for the remaining $10 \%$ and comparing to the

$$
\varepsilon=\frac{\sum_{i}^{N} \mid \text { observation }_{i}-\text { prediction }_{i} \mid}{N}
$$
estuarine waters (Williams and Esteves 2017), and a combination of both visual and statistical

21 validation is recommended for gauging model accuracy (Biondi et al. 2012). Because the models

22 presented here are not intended to be used for engineering or design input, but rather for 
1 ecological studies, a satisfaction criterion of $\mathrm{R}^{2}>0.5$ and $\varepsilon<0.1 \mathrm{~m}$ was implemented.

2 Hydrographs of observed and predicted water levels were also inspected to ensure satisfactory

3 agreement. Models not meeting these criteria in both calibration and validation periods are thus

4 reported on but excluded from hypothesis testing.

\section{$5 \quad$ Flooding Parameters}

The resulting time series of water levels were analyzed for daily flooding parameters of mean flood duration, mean dry duration, mean flood frequency, average depth, and percent of time flooded. The same parameters were calculated for each month in the time series to

9 correspond to monthly water quality measurements. Water levels were separated into flood $(\geq 0)$ and dry $(<0)$ conditions, and analyzed for length, frequency, and mean at the daily and monthly

11 level.

\section{Statistical Tests}

17 non-urban sites, defined as those with and without any urban area within the $0.5 \mathrm{~km}$ sampling

18 radius, student t-tests were used through the t.test function of base R. Linear models were

20 plotted using the ggplot function from the ggplot2 package and linear and logarithmic models

21 through the stat_smooth function (Wickham 2009). 


\section{RESULTS}

\section{Model Accuracy and Constituent Importance}

Water level model fits varied across the systems (Figures $3 \& 4$ ). For the calibration period, all models explain fifty percent or more of the variation in observed water levels $\left(\mathrm{R}^{2}\right)$ and eight $(57 \%)$ of the models explain seventy percent or more of the variation in water levels (Figure $3 b$ \& $4 b$ ). Mean absolute error $(\varepsilon)$ among all models during the calibration period was $7.4 \mathrm{~cm}$ (Figure $3 \mathrm{~b} \& 4 \mathrm{~b}$ ). Validations for all models performed marginally worse than calibrations, with only twelve of the models explaining fifty percent or more of the variation in water levels, and a mean absolute error of $4.4 \mathrm{~cm}$ (Figure $3 \mathrm{c} \mathrm{\&} \mathrm{4c).} \mathrm{Two} \mathrm{models,} \mathrm{LEVMAX} \mathrm{and}$ PONMAX, did not meet the criteria set for satisfactory agreement with observations in both calibration and validation periods $\left(\mathrm{R}^{2}>0.5, \varepsilon<0.1\right)$. These sites are thus reported on in figures as faded symbols and are excluded from further hypotheses testing involving flooding dynamics.

Constituent influences on the water levels varied in importance across the studied systems (Table 4, Table 5). The following percentages represent the contributions of each constituent, or group of constituents, to the observed variations in water levels. In the northern sites of the San Juan Bay Estuary and in Levittown, the three most important constituents were the principal lunar semi-diurnal (M2), two lunar diurnals (K1 \& O1). Fifty-three, and fifty-four percent of the water level variations in Piñones (PIN) and San José Lagoons (SAN), respectively, were explained by the short and long-term precipitation models and the water levels at PIN could not be modeled using tidal constituents. In contrast, in the San Juan Bay (BAHMIN \& BAHMAX) and in the dredged portion of the Caño Martin Peña (MPNMIN), precipitation explained less than $1 \%$ of the variation in water levels. In Levittown, the K1, M2 and O1 constituents combined and along with rainfall explained $45 \%$ and $54 \%$ of the variation in water 


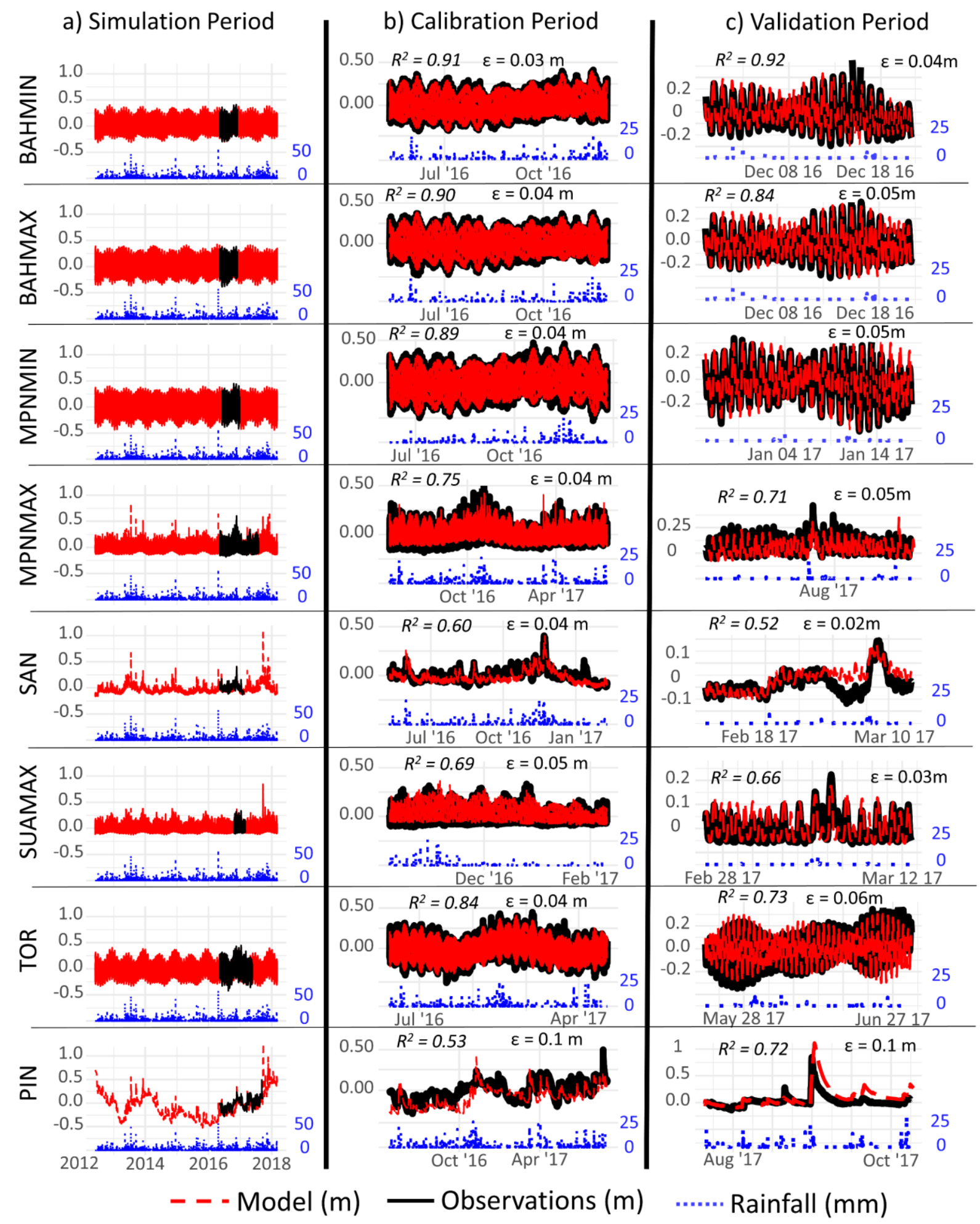

Figure 3 Rainfall, water level observations, and water level models in the San Juan Bay Estuary for the entire length of the analysis, 2012 - 2017 (a), for the observation period at each location (b), and for the validation period (c). Water levels are in reference to the mean and are plotted on the right axis. Rainfall is hourly and is plotted on the right axis. Water levels in (a) and (b) are on a fixed scale to highlight the difference in ranges between locations. Water level ranges in all other panels are unique for each location. Observations and models for SANMIN, SANMAX and SUAMIN were nearly identical, and are thus here referred to as SAN. 


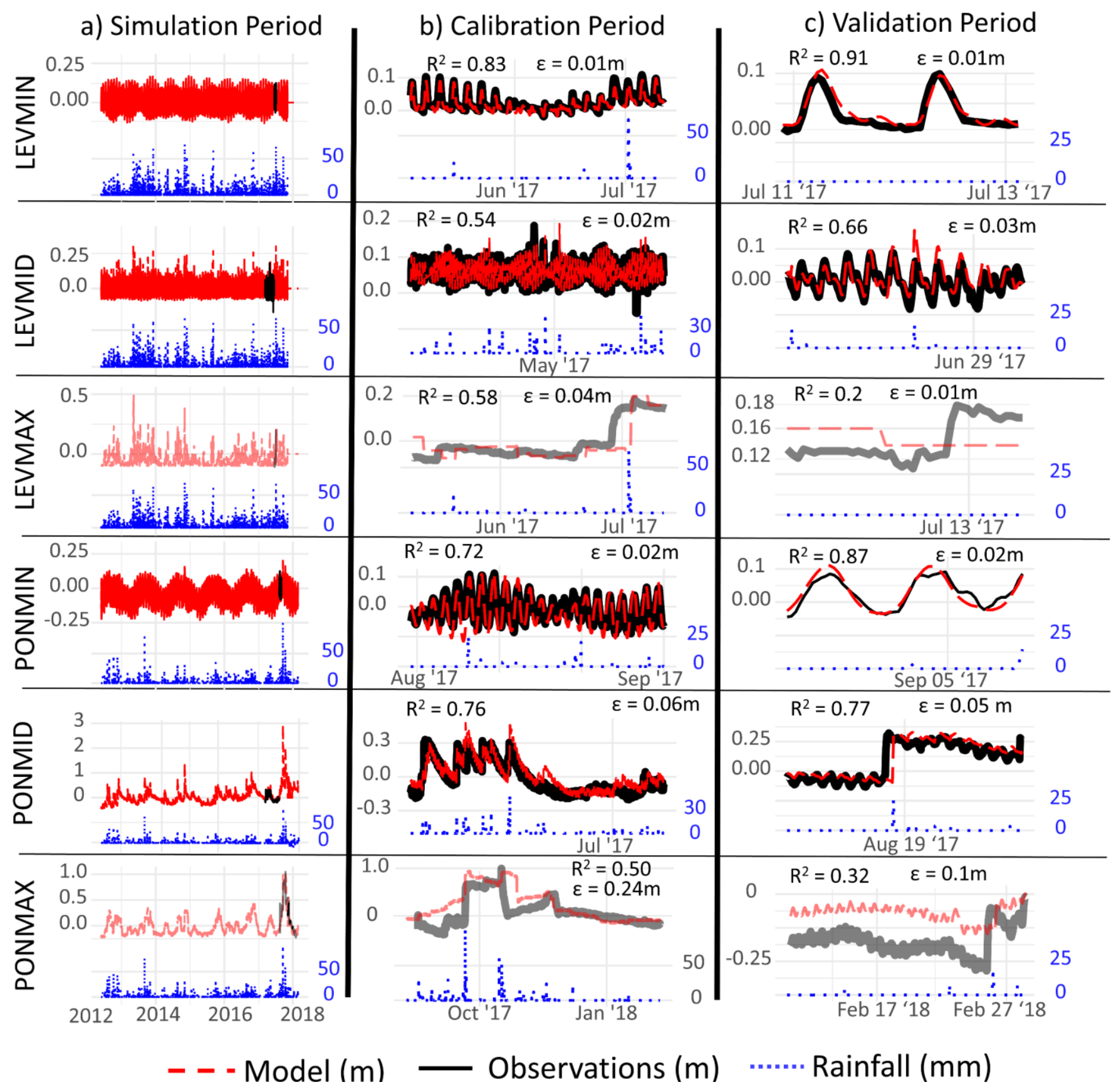

Figure 4 Rainfall, water level observations, and water level models in Levittown and Ponce for the entire length of the analysis, 2012 - 2017 (a), for the observation period at each location (b), and for the validation period (c). Water levels are in reference to the mean and are plotted on the right axis. Rainfall is hourly and is plotted on the right axis. Water levels in (a) and (b) are on a fixed scale to highlight the difference in ranges between locations. Water level ranges in all other panels are unique for each location. Models for LEVMAX and PONMAX did not meet validation criteria and are thus excluded from future hypothesis testing. 
bioRxiv preprint doi: https://doi.org/10.1101/423434; this version posted September 21, 2018. The copyright holder for this preprint (which was not certified by peer review) is the author/funder, who has granted bioRxiv a license to display the preprint in perpetuity. It is made available

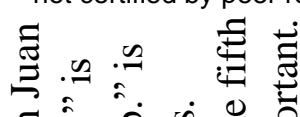

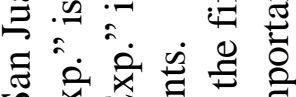

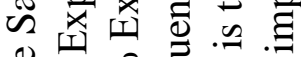

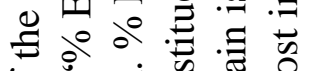

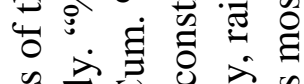

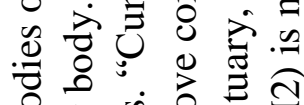
它 䒕 芆

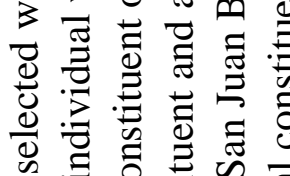
\&

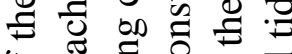

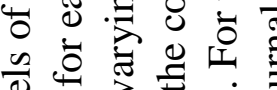
¿ 0 氙 늘 疍.

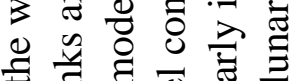

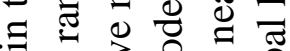

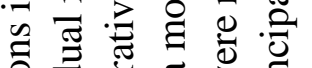

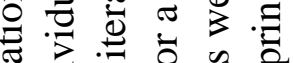

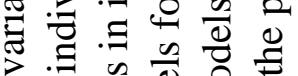

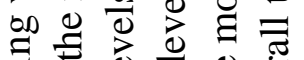

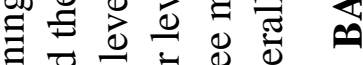

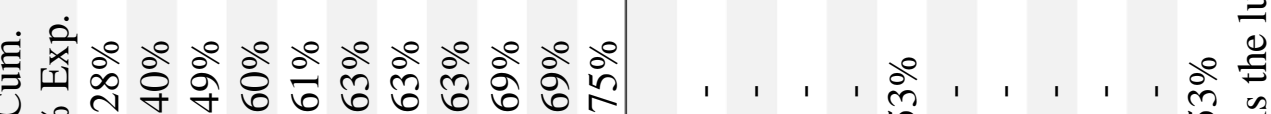
叓 वर ते 寸

光 n.

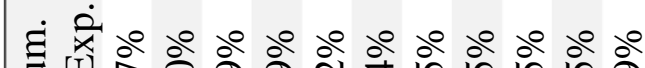
0
0

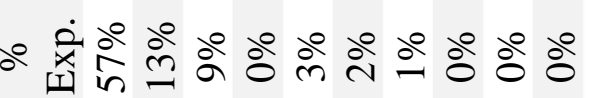
苂 - n

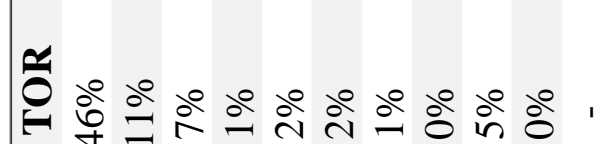
节

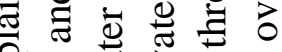

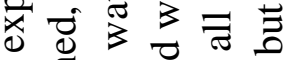

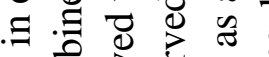

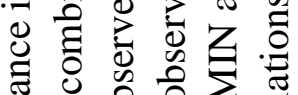
:

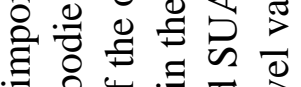
:

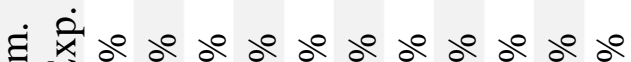

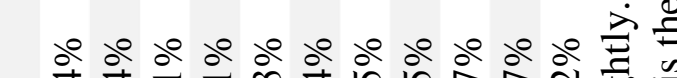
$\exists$ जी

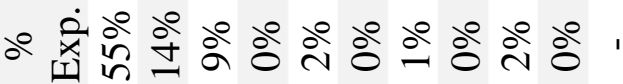

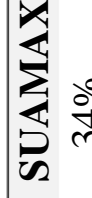
光 $-2 m$ 으

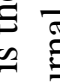

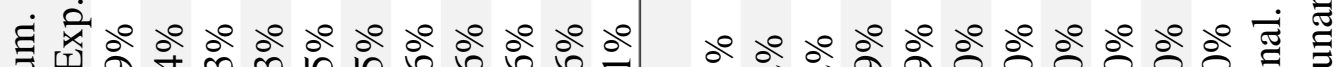
मे

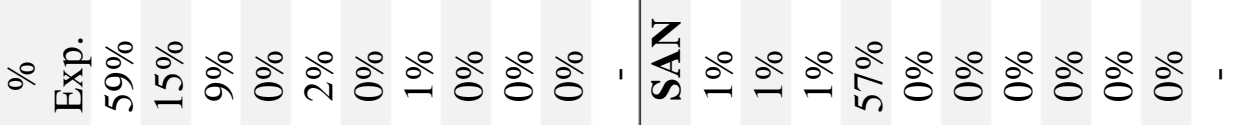
灵 $-N m$ m 需

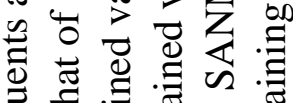

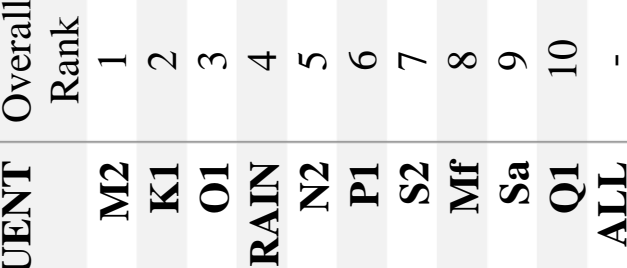
- nm+n 를 
Table 5 Water level model constituents and their importance in explaining variations in the water levels of the selected waterbodies of Levittown and Ponce. The overall rank is that of all waterbodies combined, and the individual ranks are those for each individual water body. "\% Exp." is the mean contribution to the explained variance of the observed water levels in iterative models with varying constituent orders. "Cum. \% Exp." Is the cumulative percent of the explained variation in the observed water levels for a model containing the constituent and all above constituents. In levittown, rain is the tenth most important constituent in explaining water level variations, and overall the principal lunar semidiurnal tidal constituent (M2) is most important. In Ponce, Rain is the second most important constituent, behind the principal solar semidiurnal (S1).

LEVMIN

LEVMID

\begin{tabular}{|c|c|c|c|c|c|c|c|c|c|c|}
\hline CONSTITUENT & $\begin{array}{c}\text { Overall } \\
\text { Rank }\end{array}$ & Rank & $\begin{array}{c}\% \\
\text { Exp. }\end{array}$ & $\begin{array}{l}\text { Cum. } \\
\text { \% Exp. }\end{array}$ & Rank & $\begin{array}{c}\% \\
\text { Exp. }\end{array}$ & $\begin{array}{l}\text { Cum. } \\
\text { \% Exp. }\end{array}$ & Rank & $\begin{array}{c}\% \\
\text { Exp. }\end{array}$ & $\begin{array}{l}\text { Cum. } \\
\% \text { Exp. }\end{array}$ \\
\hline K1 & 1 & 1 & $18 \%$ & $18 \%$ & 2 & $17 \%$ & $17 \%$ & - & - & - \\
\hline M2 & 2 & 4 & $11 \%$ & $29 \%$ & 1 & $24 \%$ & $41 \%$ & - & - & - \\
\hline 01 & 3 & 3 & $11 \%$ & $40 \%$ & 3 & $13 \%$ & $54 \%$ & - & - & - \\
\hline 1M.1P1 & 4 & - & $0 \%$ & $40 \%$ & 4 & $5 \%$ & $59 \%$ & - & - & - \\
\hline MSF & 5 & 2 & $13 \%$ & $53 \%$ & 11 & $0 \%$ & $59 \%$ & - & - & - \\
\hline RHO1 & 6 & 7 & $3 \%$ & $55 \%$ & 7 & $0 \%$ & $59 \%$ & - & - & - \\
\hline S2 & 7 & 8 & $2 \%$ & $58 \%$ & 6 & $2 \%$ & $61 \%$ & - & - & - \\
\hline RAIN & 8 & 6 & $5 \%$ & $63 \%$ & 9 & $0 \%$ & $61 \%$ & 1 & $58 \%$ & $58 \%$ \\
\hline MF & 9 & - & $0 \%$ & $63 \%$ & 8 & $0 \%$ & $61 \%$ & - & - & - \\
\hline MM & 10 & 5 & $9 \%$ & $72 \%$ & 14 & $0 \%$ & $61 \%$ & - & - & - \\
\hline $\mathbf{A L L}$ & & - & - & $75 \%$ & - & - & $64 \%$ & - & - & $58 \%$ \\
\hline & & \multicolumn{3}{|c|}{ PONMIN } & \multicolumn{3}{|c|}{ PONMID } & \multicolumn{3}{|c|}{ PONMAX } \\
\hline P1 & 1 & 4 & $5 \%$ & $5 \%$ & 3 & $1 \%$ & $1 \%$ & - & $0 \%$ & $0 \%$ \\
\hline RAIN & 2 & 10 & $0 \%$ & $5 \%$ & 1 & $56 \%$ & $57 \%$ & 1 & $31 \%$ & $31 \%$ \\
\hline S1 & 3 & 2 & $22 \%$ & $27 \%$ & 7 & $0 \%$ & $57 \%$ & - & $0 \%$ & $31 \%$ \\
\hline K1 & 4 & 1 & $28 \%$ & $55 \%$ & 4 & $0 \%$ & $57 \%$ & 10 & $0 \%$ & $31 \%$ \\
\hline $\mathbf{0 1}$ & 5 & 3 & $19 \%$ & $74 \%$ & - & $0 \%$ & $57 \%$ & 8 & $0 \%$ & $31 \%$ \\
\hline SSA & 6 & 13 & $0 \%$ & $74 \%$ & 2 & $19 \%$ & $77 \%$ & 3 & $6 \%$ & $37 \%$ \\
\hline MSF & 7 & 9 & $0 \%$ & $74 \%$ & - & $0 \%$ & $77 \%$ & 4 & $0 \%$ & $37 \%$ \\
\hline SA & 8 & 6 & $2 \%$ & $76 \%$ & 12 & $0 \%$ & $77 \%$ & 2 & $30 \%$ & $67 \%$ \\
\hline Q1 & 9 & 5 & $2 \%$ & $78 \%$ & 9 & $0 \%$ & $77 \%$ & - & $0 \%$ & $67 \%$ \\
\hline S2 & 10 & 4 & $0 \%$ & $78 \%$ & 6 & $0 \%$ & $77 \%$ & 6 & $0 \%$ & $67 \%$ \\
\hline ALL & & - & - & $80 \%$ & - & - & $77 \%$ & - & - & $67 \%$ \\
\hline
\end{tabular}

$\mathrm{K} 1$ is the lunar diurnal. M2 is the principal lunar semidiurnal. MF is the lunisolar fortnightly. MM is the lunar monthly. MSF is the lunisolar synodic fortnightly. N2 is the larger lunar elliptic semidiurnal. O1 is the lunar diurnal. P1 is the solar diurnal. RHO1 is a diurnal. S1 is the solar diurnal. S2 is the principal solar semidiurnal. SA is the solar annual. SSA is the solar semi-annual. PSI1 is a diurnal.

2 levels at LEVMIN and LEVMID, respectively. Most of the remaining variation in water levels at

3 these two sites is explained by the luni-solar synodic fortnight (Msf) and the luni-monthly (Mm).

$4 \quad$ Fifty-eight percent of the variations in the LEVMAX station were explained only by 
5 precipitation and no tidal model could be constructed. At Ponce, the three most important

6 constituents were the two solar diurnals (S1 \& P1) and rain. These constituents explained 27\%,

$757 \%$, and $31 \%$ of the water level variations at PONMIN, PONMID, and PONMAX, respectively.

8 Rain explained $56 \%$ and $31 \%$ of the water level variations at PONMID and PONMAX,

9 respectively, and less than $1 \%$ at PONMIN.

\section{Flooding Dynamics}

Random mangrove locations throughout the study sites varied in their flooding dynamics

12 (Figure 5). Median average depths in San Juan, Levittown, and Ponce were -1.4, -6.0, and 0.08

$13 \mathrm{~cm}$, respectively, and means were significantly different among all watersheds (ANOVA; $\mathrm{p}<$

14 0.05). Ponce depths were $8.9 \mathrm{~cm}$ greater than those at Levittown (ANOVA; $\mathrm{p}<0.001$ ), and 5.8

$15 \mathrm{~cm}$ greater than those at San Juan $(\mathrm{p}<0.001)$. San Juan depths were $3 \mathrm{~cm}$ higher than Levittown

16 (ANOVA; $\mathrm{p}<0.05$ ). Median flood length in the three systems were 0.64, 0.17, and 2.3 days,

17 respectively. San Juan mean flood length was 108 days longer than Levittown and 102 days

18 longer than Ponce (ANOVA; $\mathrm{p}<0.001$ ). Median daily flood frequency, in which 0 is either

19 constantly flooded or constantly dry, were 1.0, 0.7, and 1.1 respectively in San Juan, Levittown

20 and Ponce. On average San Juan mangroves flooded 0.3 and 0.2 more times per day than in

21 Levittown and Ponce (ANOVA; $\mathrm{p}<0.001$ ), corresponding to one extra flood every 3 and 5 days,

22 respectively. Mangroves of Ponce flooded 0.2 times per day more than those of Levittown,

23 corresponding to one extra flood every 5 days (ANOVA; $p<0.01$ ). Median percent of time

24 flooded was 40,11, and 48\%, respectively, in San Juan, Levittown and Ponce. San Juan was 


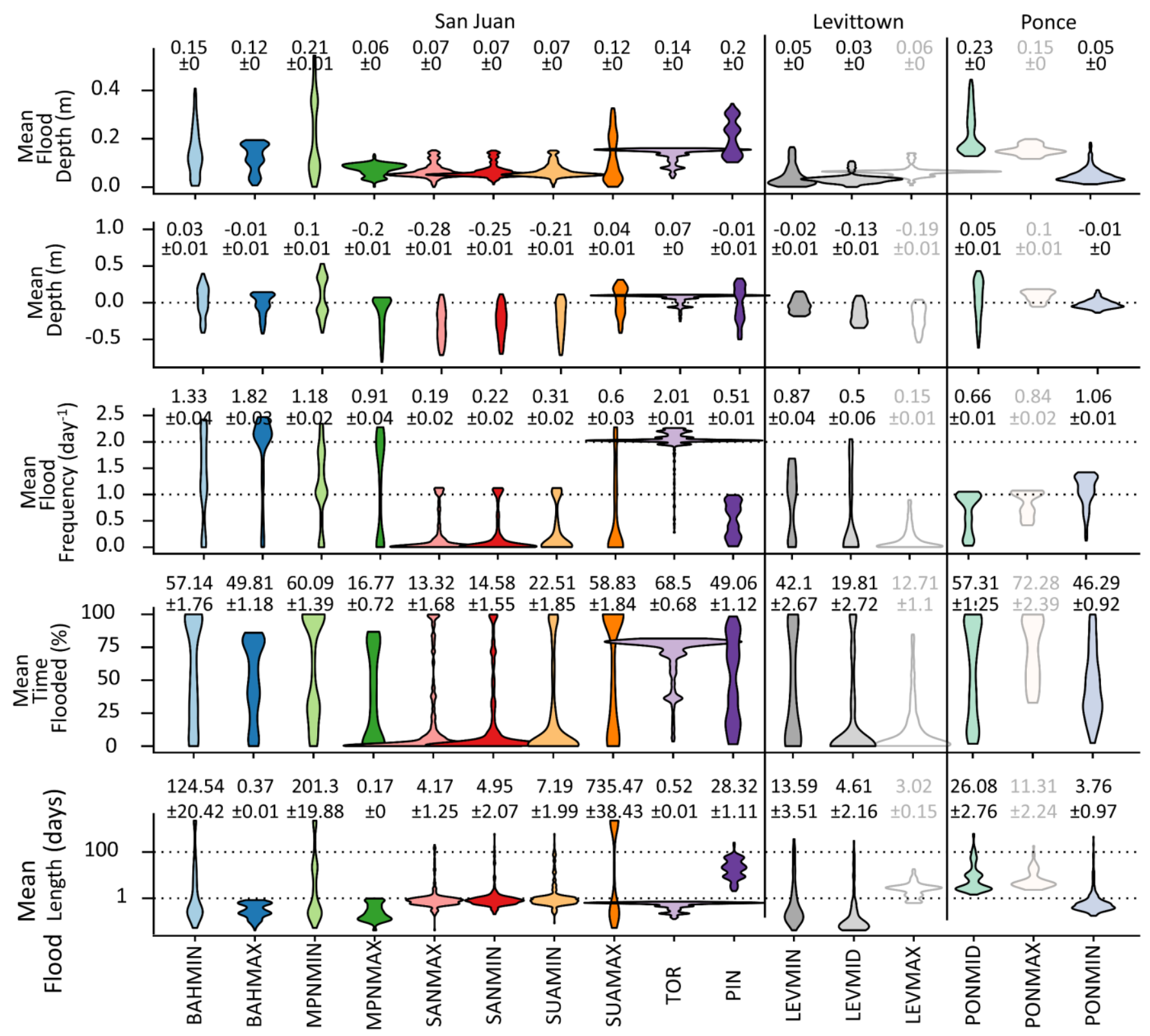

Figure 5 Violin plots of mean flooding metrics from random locations within the mangrove zones over the course of the five-year modeling period. Annotations are means and standard errors for each location. Locations are ordered from west to east in each watershed. Constantly flooded or dry locations have a flood frequency of 0 . Shapes of the violin plot are determined by value densities, with the widest portion of the "violin" being representative of the highest density of values. PONMAX, PIN, LEVMAX, and PONMID are most distinct and characterized by long hydroperiods with minimal daily flood frequencies 
flooded $13 \%$ more of the time that Levittown was flooded and $5.8 \%$ less than Ponce $(\mathrm{p}<0.001)$.

27 Ponce was flooded $19 \%$ more of the time than Levittown $(\mathrm{p}<0.001)$.

Among sites, flooding metrics were variable, and no single site was distinct in all metrics.

The dredged portion of Caño Martin Peña (MPNMIN) held the greatest average depth at $10 \mathrm{~cm}$, which was significantly different than all other sites except Torrecillas lagoon (TORMIN) (ANOVA; mean difference $=17 \mathrm{~cm}, \mathrm{p}<0.001)$. In flooded depth, PONMID was greatest at 22.5 $\mathrm{cm}$, which was significantly greater than all other sites except MPNMIN (ANOVA; mean difference $=12 \mathrm{~cm}, \mathrm{p}<0.001)$. In contrast, SANMIN experienced the lowest average depth at -

$24.6 \mathrm{~cm}$ (24.6 cm above water), which was significantly different than all sites except MPNMAX, SANMIN and SUAMIN (ANOVA; mean difference $=21 \mathrm{~cm}, \mathrm{p}<0.001$ ). days, five times longer than PONMID and at least twenty times longer than the other sites. all other sites (ANOVA; mean difference $=703$ days, $\mathrm{p}<0.001)$. In contrast, MPNMAX exhibited the shortest hydroperiod of 0.2 days, which was lower than all other sites except

\section{2 SANMAX at 0.2 day, which was lower than all other sites except SANMIN and SUAMIN} LEVMID (ANOVA; mean difference $=8$ days, $\mathrm{p}=<0.001$ ). Flood frequency was lowest at (ANOVA; mean difference $=0.7$ per day, $\mathrm{p}<0.001)$. The highest flood frequency was shown by

44 TORMIN at 2 per day, higher than all other sites (ANOVA; mean difference $=1.2$ per day, $\mathrm{p}<$ 0.001). In average depth, MPNMIN was the greatest at $0.1 \mathrm{~m}$ and greater than all other sites

$46 \quad($ ANOVA; mean difference $=0.17 \mathrm{~m}, \mathrm{p}<0.001)$, and SANMAX was the least at $-0.28 \mathrm{~m}(0.28$

$47 \mathrm{~m}$ above water), lower than all other sites except SANMIN (ANOVA; mean difference $=0.24, \mathrm{p}$ $48<0.001)$ 


\section{Surface Water Chemical Properties}

In Tukey honest significant difference tests, Piñones (PIN) was singled out in surface water chemical properties (Figure 6). This lagoon was characterized by significantly greater total Kjeldahl nitrogen (mean difference $=8.6 \mathrm{mg} / \mathrm{L} ; \mathrm{p}<0.001)$, TOC $($ mean difference $=12.9 \mathrm{mg} / \mathrm{L}$; $\mathrm{p}<0.001)$, turbidity (mean difference $=176.2 \mathrm{NTU} ; \mathrm{p}<0.001)$, and BOD $($ mean difference $=$ $15.5 \mathrm{mg} / \mathrm{L} ; \mathrm{p}<0.01)$ than all other water bodies, as well as significantly higher temperature than half of the other stations (mean difference $=1.7^{\circ} \mathrm{C} ; \mathrm{p}<0.05$ ). The BAHMAX station was also distinct in having higher salinity than all other stations (mean difference $=16.7$ PSU; $\mathrm{p}<0.001$ ). SANMIN held the highest mean nitrate and nitrite concentration but was only significantly different than BAHMIN (difference $=0.3, \mathrm{p}<0.05$ ) and SANMAX (difference $=0.3, \mathrm{p}<0.05$ ). SANMAX held the highest $\mathrm{pH}$, which was significantly different than SUAMAX (difference = $0.3, \mathrm{p}<0.01)$, TOR $($ difference $=0.3, \mathrm{p}<0.01)$, and PIN $($ difference $=0.4, \mathrm{p}<0.05)$. There were no differences in total phosphorus or oil and grease concentrations between sites.

\section{Land cover, Surface Water Chemistry and Flood Dynamics} by surrounding land cover (Figure 7). All metrics except nitrate and nitrite, total phosphorus (P), dissolved oxygen (DO), $\mathrm{pH}$ and salinity resulted in significant models when predicted by surrounding land cover. However, almost all models were significant only because of an outlier site, PIN (Piñones lagoon), and could not be repeated when this site was removed from the analysis. Biological oxygen demand was the only metric to be significantly modeled with or without the PIN site, and resulted in a negative relationship with surrounding road length $\left(\mathrm{R}^{2}=\right.$ $0.59, \mathrm{p}<0.05)$. Otherwise, trends suggest decreasing nitrogen, carbon, turbidity, oil, and temperature with increasing urbanization. Salinity was found to significantly increase with flood 


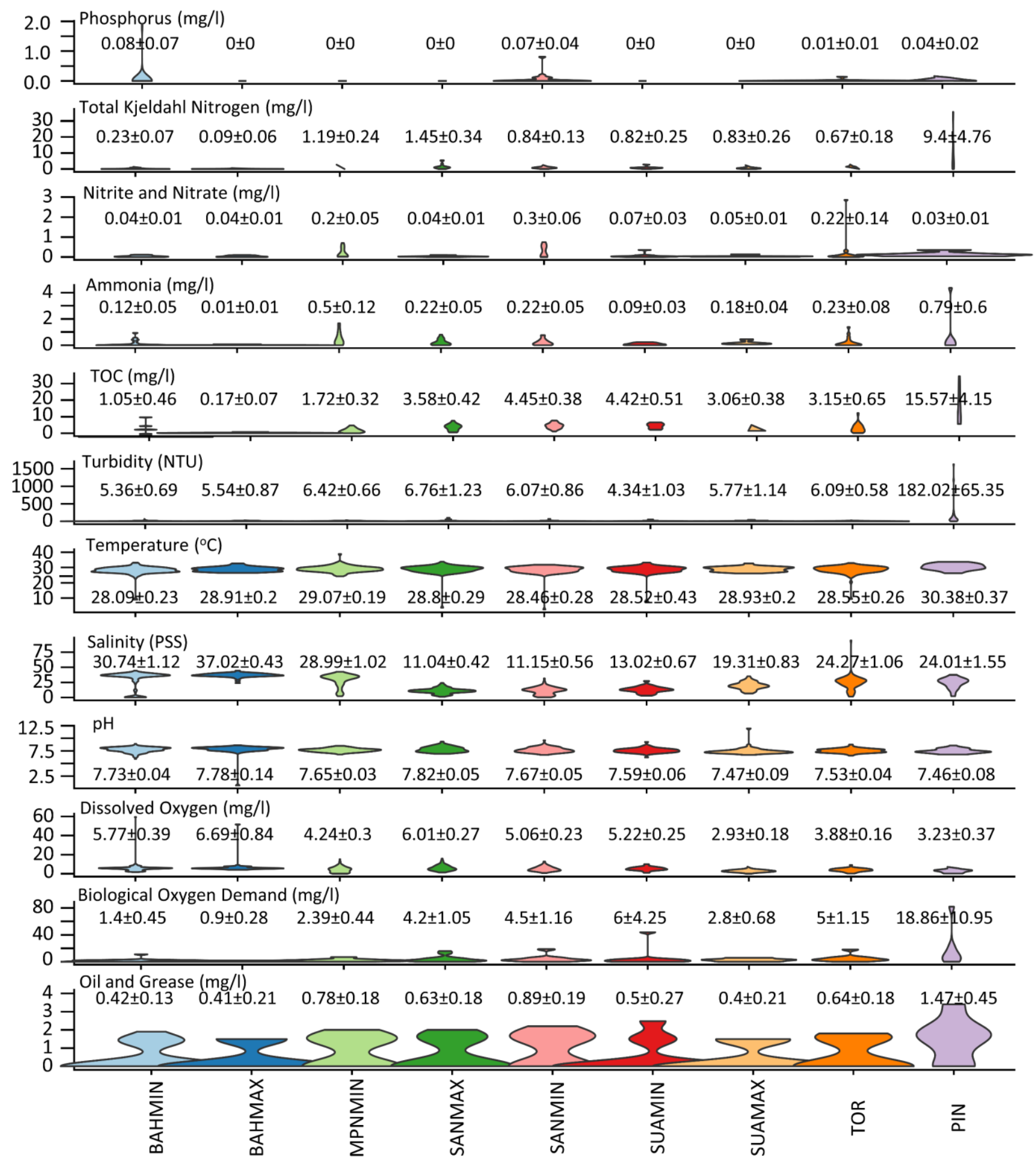

Figure 6 Violin plots of water chemistry throughout the San Juan Bay Estuary. Annotations are means and standard errors for each location. Nitrogen concentrations were abnormally high in some of the waterbodies, which may be associated with sewage effluent. PIN was most distinct, with significantly higher TOC, Kjeldahl nitrogen, and temperature in comparison to the other water bodies 
73 frequency (linear model; $\mathrm{R}^{2}=0.55, \mathrm{p}<0.05$ ), and oil and grease concentrations were found to

74 increase with flooding duration and proportion of time flooded (linear models; $\mathrm{R}^{2}=0.5, \mathrm{p}<$

$750.05)$.

Flooding metrics resulted in much fewer significant linear models compared to surface

77 water chemical properties when predicted by surrounding land coverage (Figure 8). In t-tests

78 between urban and non-urban sites, however, in which urban is defined as any urban cover

79 within the $0.5 \mathrm{~km}$ sampling radius, most metrics resulted in significant differences. Mean water

80 depth and the proportion of time flooded were the only flooding metrics to result in significant

81 linear models $(\mathrm{p}<0.05)$. In both cases, the surrounding open water and vegetation coverage was

82 the strongest predictor and resulted in positive linear relationships. However, much of the

83 significance of these models may only be due to the highly urban outlier site of MPNMAX, and

84 none of the models resulted in significant slopes when this site was removed from the analysis.

85 In binomial comparisons of urban and non-urban sites through t-tests, all metrics except flooding

86 frequency were statistically different. These tests suggest urban sites have lower depth but longer

87 hydroperiod and overall lower proportion of time flooded.

In testing the response of specific tidal and rainfall constituents to surrounding land 


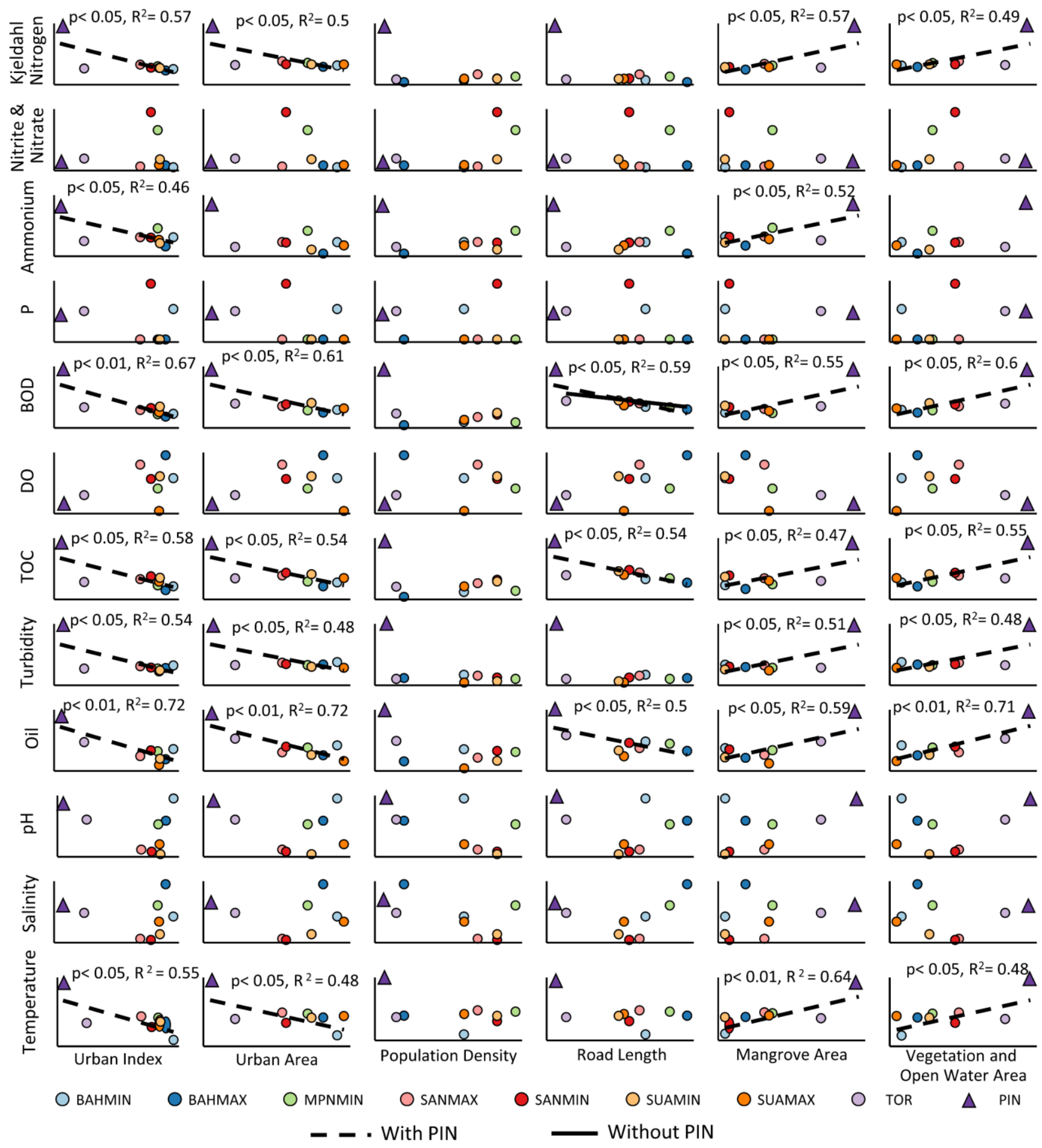

Figure 7 Scatter plots and linear models of surface water chemistry metrics as predicted by surrounding land cover. Lines show statistically significant models $(\mathrm{p}<0$.05). Dashed lines are those with all sites and the solid line is that without PIN, which was an outlier and responsible all but one of the significant models. Biochemical oxygen demand, nitrogen concentrations, organic carbon, turbidity, oil and grease, and temperature are all predicted to decrease with increasing urbanization 


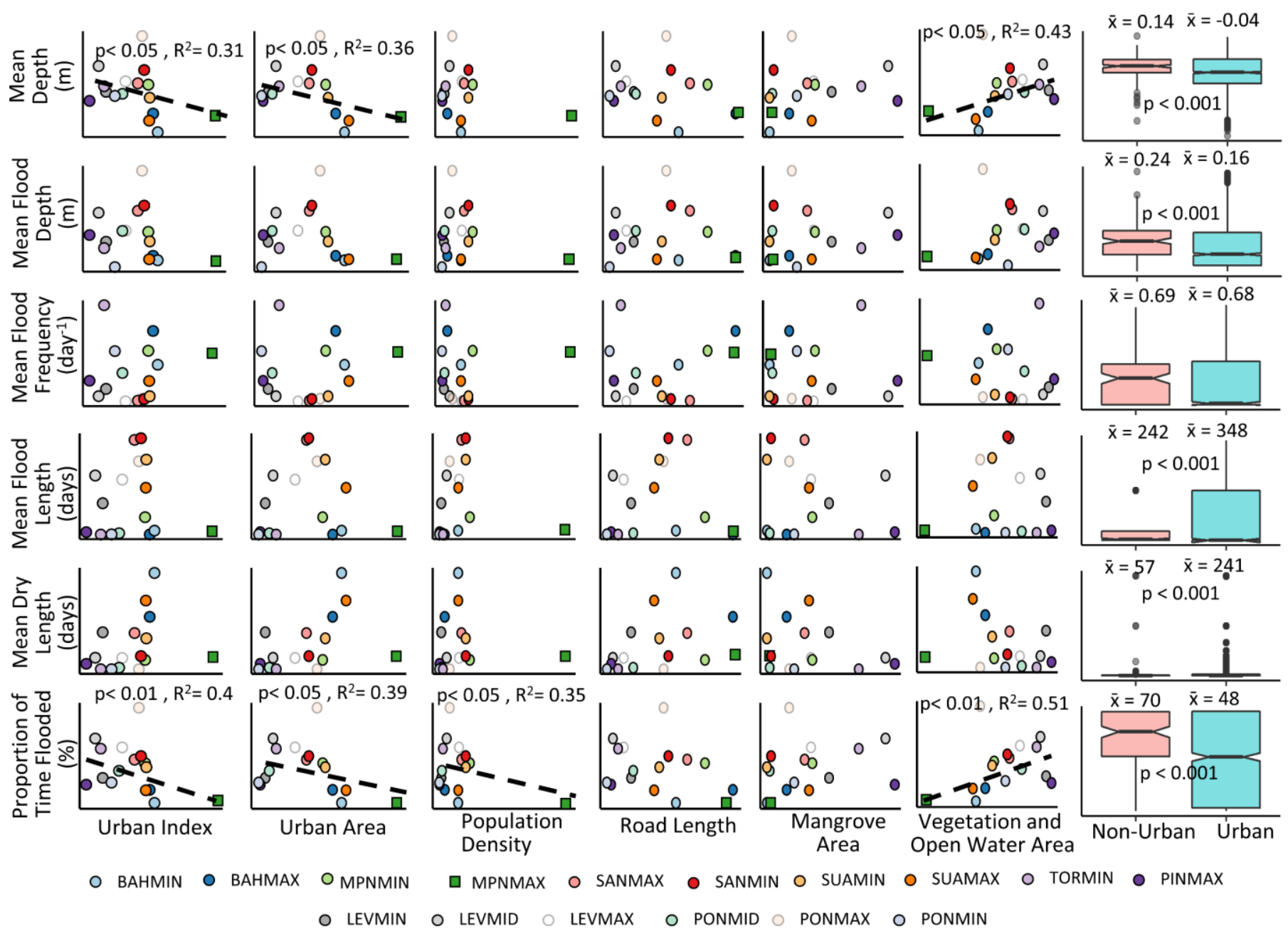

Figure 8 Scatter plots, linear models, and boxplots of flooding metrics as predicted by surrounding land cover. In scatterplots, lines show statistically significant models $(\mathrm{p}<0.05)$. None of the linear models could be repeated without the outlier of MPNMIN. In boxplots, Urban is defined as those points with any urban land cover within the $0.5 \mathrm{~km}$ sampling radius. P-values are the result of student $\mathrm{t}$ tests and are displayed only when a significant difference resulted between urban and non-urban values. Under this definition, there are significant differences in urban and non-urban mangroves in all flooding metrics except flood frequency. These results suggest urban mangrove are shallower and flooded less of the time than non-urban mangroves. 
a)
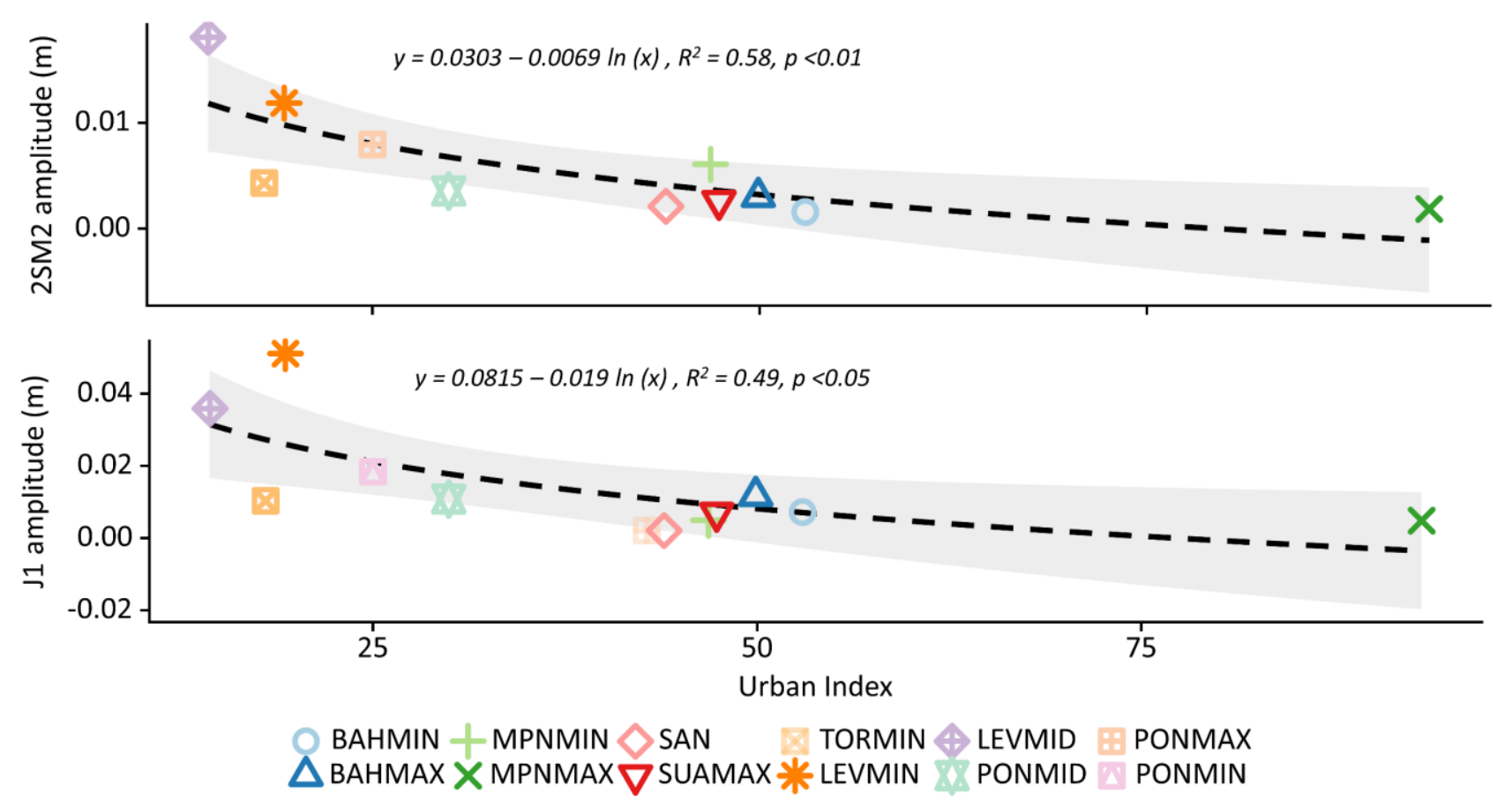

b)

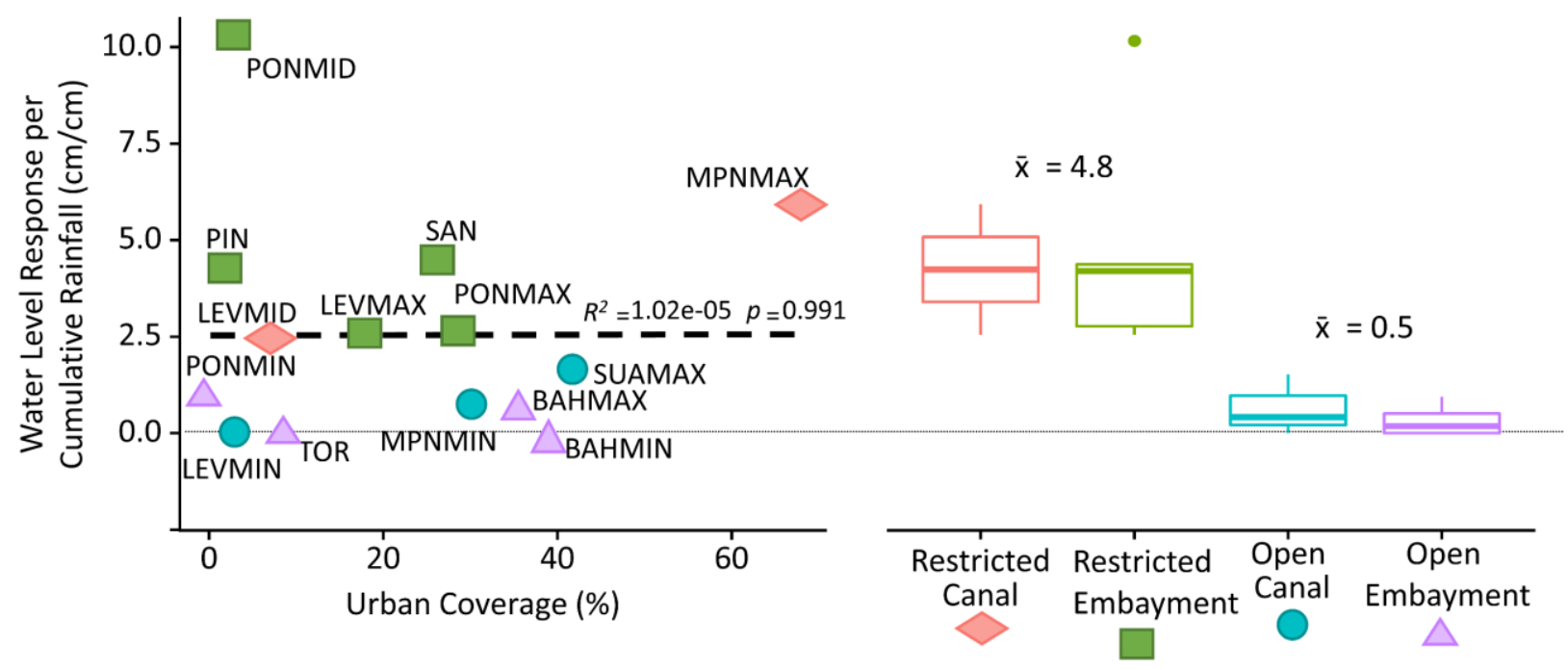

Figure 9 Mixed evidence for the influence of urban land use on mangrove hydrology. The shallow water semidiurnal (2SM2) and the smaller lunar elliptical diurnal (J1) tidal constituents show decreasing amplitude with increasing urban coverage (a). But there was no evidence for an effect of urbanization on water level responses to rainfall (b). Instead, differences in rainfall response were best explained by geomorphology, where partially restricted waterbodies respond more sharply to rainfall than to those that are more open to tidal connections. 
99 increasing water levels five times that of cumulative rainfall. This was significantly greater than

100 the response by open systems at 0.5 times cumulative rainfall $(\mathrm{t}$ test; difference $=4.2 \mathrm{~cm} / \mathrm{cm}, \mathrm{p}<$

101 0.05). There was no relationship between the extent of water level response to rainfall and

102 surrounding urban coverage across sites $(\mathrm{p}>0.5)$.

\section{DISCUSSION}


122 rainfall runoff to the point in which it interferes with otherwise normal tidal forcing. This would

123 be consistent with urban hydrology theory (Leopold 1968; Hollis 1975; Lee et al. 2006; Dietz

124 and Clausen 2008). But tidal models were constructed in the absence of rainfall within a 4-day

125 period, so all tidal amplitudes should be independent of the influence of precipitation. Further,

126 there was no significant effect of urbanization on the water level responses to rainfall (Figure

127 9b). Instead, tidal connectivity resulting from geomorphology was found to be more important,

128 where restricted and less connected systems respond more strongly to rainfall than do open and

129 more connected systems (Figure 9b). Urbanization might therefore be influencing tidal

130 components through engineered changes to geomorphology.

Canalization and dredging, for example, are sometimes associated with highly urban

132 landscapes, and are also likely influencing tidal amplitudes through changes in geomorphology.

133 There was some evidence for this in the results. Water levels in the dredged portion of Martín

134 Peña canal (MPNMIN) are nearly identical to those at the mouth of the Río Puerto Nuevo in the

135 San Juan Bay (BAHMAX) (Figure 3). Farther into the un-dredged and highly constricted Martín

136 Peña (MPNMAX), however, daily water ranges are nearly half that of MPNMIN and the

137 influence of rain on the water level model is five times greater (Table 4, Figure 9b). Thus, it is

138 likely that the dredging of the lower portions of the canal has allowed greater tidal influence and

139 limited response to rainfall. A similar reduction in tidal amplitude and amplification of the

140 importance of rain is seen between SUAMAX and SUAMIN (Figure 3). These two portions of

141 the Suarez canal are separated by the Baldorioty expressway (PR highway 66) and a network of

142 frontage roads that form a highly engineered constriction, reducing the canal width from roughly

14350 to 15 meters. The restricted portion of the canal at SUAMIN and San Jose Lagoon stations

144 (SANMIN and SANMAX), the daily range in water levels is 3.5 times less than that at the tidally 
connected SUAMAX and the importance of rain in the water level model is nearly six times greater (Table 4, Figure 9b). Thus, the constriction of the canal at the highway crossing is likely impeding flood drainage, resulting in greater importance of rainfall and limited tidal connectivity in the upper half of the canal.

With surface water chemical properties, the most significant models could not be repeated without the extreme values of Piñones lagoon (PIN), which is a relatively pristine system with a weak hydrologic connection to the rest of the estuary (Ellis 1976; Lugo et al. 2011). Biological oxygen demand, however, was modeled to decrease as surrounding road length increased in models with and without PIN. But the effect of street lengths on BOD is opposite of that from previous studies (Mallin et al. 2009; Erickson et al. 2013), which have shown urban storm water runoff to increase BOD by introducing oxygen demanding substances. The observed trend from Figure 7 is thus probably spurious as it is unlikely street length in San Juan has the opposite effect on BOD as other aquatic systems. Instead, the observed trend is likely due to elevated organic carbon (TOC) and nitrogen (Kjeldahl nitrogen) at Piñones (Sawyer 2003). A linear model constructed of these two predictors performed far better than any of the tested land cover metrics $\left(\mathrm{BOD} \sim \mathrm{TOC}+\mathrm{Kjeldahl}\right.$ nitrogen; $\left.\mathrm{R}^{2}=0.98, \mathrm{p}<0.01\right)$. Apart from BOD, TOC and Kjeldahl nitrogen, Piñones held significantly higher ammonia, turbidity, oil and grease, and temperature, than most other sites, and all trends suggest the opposite of previous studies in which the least urban water bodies hold the lowest nutrient and contaminant concentrations (McClelland and Valiela 1998; Mallin et al. 2009; Erickson et al. 2013). Thus, Piñones being a relatively pristine system, it must be inferred that its anomalous surface water chemistry is explained more by its minimal tidal influence than by urban inputs. This further demonstrates that hydrology and water chemistry must by studied within the context of geomorphology and 
168

169

tidal connectivity when assessing anthropogenic influences (Kjerfve et al. 1999; Adame et al. 2010).

There are other examples of isolated abnormalities that could be associated with either urbanization or natural variations in geomorphology and water chemistry. For the former, nitrogen was abnormally high in various forms in some of the water bodies of the San Juan Bay Estuary, providing further evidence for the commonly reported eutrophication of the system (Webb and Gómez-Gómez 1998; Cerco et al. 2003). Ammonia on average was four times higher in Piñones, a relatively pristine site, than the other water bodies, and total Kjeldahl nitrogen was ten times higher. Similar patterns have been seen in other landward mangroves with less tidal connectivity and some human inputs (Tam and Wong 1998). SANMIN, a moderately urban site, also registered higher nitrate and nitrite concentrations than all other water bodies, this time likely due to an excessive amount of wastewater entering the lagoon from the surrounding area through the San Antón creek (Gómez-Gómez and Quiñones 1983). Sewage may also be to blame for high phosphorous concentrations at BAHMIN, which includes the mouth of Malaria canal and the intermittent effluent of sewage (Cruden 2015). Piñones was again singled out from the other water bodies in its flooding dynamics, along with LEVMAX, PONMAX, and PONMID, all of which exhibited significantly greater hydroperiods and maximum flood depths in comparison with the other sites. Again, the likely reasons for these anomalies are mixed. These mangroves are characterized by relatively isolated inland lagoons with little tidal connectivity. As a result, they are more sensitive to precipitation inputs (Rodríguez-Martínez and Soler-López 2014), which induce rapid and prolonged flooding. At PONMAX and LEVMAX, the isolation is likely by design, with both serving as urban storm water retention basins. But Piñones and 

specific influences along quantified urban gradients in mangrove systems. This study shows that

PONMID are both protected and relatively undisturbed sites with minimal human influence, thus their abnormal hydroperiods are more likely a result of natural forces.

This study used water level models based on months and in some cases years of observations across sixteen sites in Puerto Rico. Most of the models explained more than 50\% of the observed variations in water levels, and many of them explained at least $70 \%$ of the variations. Still, unexplained variations may be a result of untested variables or biased or inaccurate results. One potential source of error is the vertical accuracies of the DEMs (Table 1), which although well within the range of most water levels, are still greater than some of the observed differences in depths between sites. More accurate DEMs that cover such a large area may be available for future studies and could be used to improve upon this study. Other improvements can be made by capturing more long-term observations across similarly quantified urban gradients, and by capturing the response to rainfall, which was the primary source of unexplained variation. These studies should consider land cover alongside geomorphology and tidal connectivity, and should attempt to isolate tidal constituents and specific urban components. They should also use varying definitions of urbanness, as it was demonstrated here that binomial classifications of urban and non-urban resulted in significant differences while gradient analyses did not. Doing so will identify potential causal factors and will be an increasingly important task for mangrove management in the Anthropocene.

As urbanization continues to drive ecosystem processes and habitat loss, its influence on mangrove hydrology is not yet well understood. While changes to hydrology and water chemistry are well documented in urban systems, there remains little empirical evidence for such evidence remains confounded with other important factors along three urban gradients in 
213 Puerto Rico. Although there was some evidence for changes in tidal amplitudes and surface

214 water chemical properties in urban sites, there were few consistent trends to tie any variations in

215 water levels or chemistry to surrounding urbanization. Geomorphology and tidal connectivity

216 were found to be important influences, both of which exhibit both natural and anthropogenically

217 induced variations. Future studies must therefore distinguish between specific components of

218 urban landscapes and natural or engineered variations in geomorphology. They may also

219 improve upon the results presented here by using more accurate DEMs and by better capturing

220 the uncertainty in water level responses to rainfall.

\section{REFERENCES}

Acevedo-Figueroa D, Jiménez BD, Rodriguez-Sierra CJ (2006) Trace metals in sediments of two estuarine lagoons from Puerto Rico. Environ Pollut 141:336-342

Adame MF, Virdis B, Lovelock CE (2010) Effect of geomorphological setting and rainfall on nutrient exchange in mangroves during tidal inundation. Mar Freshw Res 61:1197-1206

Altunkaynak A (2007) Forecasting surface water level fluctuations of Lake Van by artificial neural networks. Water Resour Manag 21:399-408

Bates D, Mullen KM, Nash JC, Varadhan R (2014) minqa: Derivative-free optimization algorithms by quadratic approximation

Biondi D, Freni G, Iacobellis V, et al (2012) Validation of hydrological models: Conceptual basis, methodological approaches and a proposal for a code of practice. Phys Chem Earth, Parts A/B/C 42:70-76

Bivand R, Rundel C (2017) rgeos: Interface to Geometry Engine - Open Source (GEOS)

Bivand RS, Pebesma E, Gomez-Rubio V (2013) Applied spatial data analysis with R, Second edition. Springer, NY, NY, USA

Bosire JO, Dahdouh-Guebas F, Walton M, et al (2008) Functionality of restored mangroves: a review. Aquat Bot 89:251-259

Bouillon S, Middelburg JJ, Dehairs F, et al (2007) Importance of intertidal sediment processes and porewater exchange on the water column biogeochemistry in a pristine mangrove creek (Ras Dege, Tanzania). Biogeosciences Discuss 4:317-348

Brandeis TJ, Escobedo FJ, Staudhammer CL, et al (2014) San Juan Bay Estuary watershed urban 
forest inventory. Gen Tech Rep SRS-GTR-190 Asheville, NC USDA-Forest Serv South Res Station 44 p 190:1-44

Branoff BL (2017) Quantifying the influence of urban land-use on mangrove biology and ecology: A meta-analysis. Glob Ecol Biogeogr 26:1339-1356

Bunch BW, Cerco CF, Dortch MS, et al (2000) Hydrodynamic and water quality model study of San Juan Bay Estuary. ARMY ENGINEER WATERWAYS EXPERIMENT STATION VICKSBURG MS ENGINEER RESEARCH AND DEVELOPMENT CENTER

Cerco C, Bunch B, Dortch M, et al (2003) Eutrophication and pathogen abatement in the San Juan Bay Estuary. J Environ Eng 129:318-327

Clough BF, Boto KG, Attiwill PM (1983) Mangroves and sewage: a re-evaluation. In: Teas H (ed) Biology and ecology of mangroves. Springer Netherlands, pp 151-161

Colonnello G, Medina E (1998) Vegetation changes induced by dam construction in a tropical estuary: the case of the Mánamo river, Orinoco Delta (Venezuela). Plant Ecol 139:145-154

Cruden JC (2015) United States of America v. Commonwealth of Puerto Rico

Dawson CW, Wilby R (1998) An artificial neural network approach to rainfall-runoff modelling. Hydrol Sci J 43:47-66

Dietz ME, Clausen JC (2008) Stormwater runoff and export changes with development in a traditional and low impact subdivision. J Environ Manage 87:560-566

Ellis SR (1976) History of dredging and filling of lagoons in the San Juan area, Puerto Rico

Ellison AM, Farnsworth EJ (1996) Anthropogenic Disturbance of Caribbean Mangrove Ecosystems: Past Impacts, Present Trends, and Future Predictions. Biotropica 28:549-565. doi: $10.2307 / 2389096$

Erickson AJ, Weiss PT, Gulliver JS (2013) Impacts and composition of urban stormwater. In: Optimizing Stormwater Treatment Practices. Springer, pp 11-22

Ewel K, Twilley R, Ong JIN (1998) Different kinds of mangrove forests provide different goods and services. Glob Ecol Biogeogr Lett 7:83-94

Faulkner S (2004) Urbanization impacts on the structure and function of forested wetlands. Urban Ecosyst 7:89-106

Feller IC, Whigham DF, McKee KL, Lovelock CE (2003) Nitrogen limitation of growth and nutrient dynamics in a disturbed mangrove forest, Indian River Lagoon, Florida. Oecologia $134: 405-414$

Gleeson J, Santos IR, Maher DT, Golsby-Smith L (2013) Groundwater-surface water exchange in a mangrove tidal creek: evidence from natural geochemical tracers and implications for nutrient budgets. Mar Chem 156:27-37

Gómez-Gómez F, Quiñones F (1983) Hydrologic charactersitics of lagoons at San Juan, Puerto Rico, during an October 1974 tidal cycle

Grömping U (2006) Relative Importance for Linear Regression in R: The Package relaimpo. J 
Stat Softw 17:1-27

281

282

283

284

285

286

287

288

289

290

291

292

293

294

295

296

297

298

299

300

301

302

303

304

305

306

307

308

309

310

311

312

313

314

315

Hamilton S, Casey D (2016) Creation of a high spatiotemporal resolution global database of continuous mangrove forest cover for the 21st Century (CGMFC-21). Glob Ecol Biogeogr 25.6:729-738

Hijmans R (2016) raster: Geographic Data Analysis and Modeling

Hollis GE (1975) The effect of urbanization on floods of different recurrence interval. Water Resour Res 11:431-435

Kjerfve B, Lacerda LD, Rezende CE, Ovalle ARC (1999) Hydrological and hydrogeochemical variations in mangrove ecosystems. Mangrove Ecosyst Trop Am Struct Funct Manag A Lara-Dominquez, AL eds) INECOL (Mexico), IUCN/ORMA (Costa Rica), NOAA/NMFS (Beaufort, NC, USA) 71-81

Kossieris P, Tyralis H, Koutsoyiannis D, et al (2016) HyetosMinute: A package for temporal stochastic simulation of rainfall at fine time scales

Krauss KW, Doyle TW, Twilley RR, et al (2006) Evaluating the relative contributions of hydroperiod and soil fertility on growth of south Florida mangroves. Hydrobiologia 569:

Lee SY, Dunn RJK, Young RA, et al (2006) Impact of urbanization on coastal wetland structure and function. Austral Ecol 31:149-163

Lee SY, Primavera JH, Dahdouh-Guebas F, et al (2014) Ecological role and services of tropical mangrove ecosystems: a reassessment. Glob Ecol Biogeogr 23:726-743

Leopold LB (1968) Hydrology for urban land planning: A guidebook on the hydrologic effects of urban land use

Lewis RR (2005) Ecological engineering for successful management and restoration of mangrove forests. Ecol Eng 24:403-418

Lindeman RH (1980) Introduction to bivariate and multivariate analysis

Lovelock CE, Ball MC, Martin KC, C. Feller I (2009) Nutrient Enrichment Increases Mortality of Mangroves. PLoS One 4:e5600. doi: 10.1371/journal.pone.0005600

Lugo AE, Medina E (2014) Mangrove Forests. In: Encyclopedia of Natural Resources. Taylor \& Francis, New York, NY, pp 343-352

Lugo AE, Ramos O, Rodriguez C (2011) The Río Piedras watershed and its surrounding environment. FS-980 US Dep Agric For Serv Int Inst Trop For 46 p 980:

Lugo AE, Snedaker SC (1974) The ecology of mangroves. Annu Rev Ecol Syst 39-64

Mallin MA, Johnson VL, Ensign SH (2009) Comparative impacts of stormwater runoff on water quality of an urban, a suburban, and a rural stream. Environ Monit Assess 159:475-491

Mandura AS (1997) A mangrove stand under sewage pollution stress: Red Sea. Mangroves Salt marshes 1:255-262

Marois DE, Mitsch WJ (2017) A mangrove creek restoration plan utilizing hydraulic modeling. 
Ecol Eng 108:537-546

Martinuzzi S, Gould WA, Lugo AE, Medina E (2009) Conversion and recovery of Puerto Rican mangroves: 200 years of change. For Ecol Manage 257:75-84

McClelland JW, Valiela I (1998) Linking nitrogen in estuarine producers to land-derived sources. Limnol Oceanogr 43:577-585

McMahon G, Cuffney TF (2000) Quantifying urban intensity in crainage basins for assessing stream ecological conditions. J Am Water Resour Assoc 36:1247-1261

Medina E (1999) Mangrove physiology: the challenge of salt, heat, and light stress under recurrent flooding. Ecosistemas Mangl en América Trop 109-126

NOAA (2015a) San Juan, Puerto Rico 1/9 arc-second PRVD Coastal Digital Elevation Model

NOAA (2015b) 2015 NOAA NGS Topobathy Lidar DEM: Puerto Rico

NOAA Biogeography Program (2011) Benthic Habitats of Puerto Rico

Office for Coastal Management (2017) C-CAP Land Cover, Puerto Rico, 2010. Charleston, SC

Powell MJD (2009) The BOBYQA algorithm for bound constrained optimization without derivatives. Cambridge NA Rep NA2009/06, Univ Cambridge, Cambridge 26-46

Rodríguez-Martínez J, Soler-López LR (2014) Hydrogeology and hydrology of the Punta

Sakho I, Mesnage V, Deloffre J, et al (2011) The influence of natural and anthropogenic factors Sci 94:93-101

Sawyer CN (2003) Chemistry for environmental engineering and science. McGraw-Hill

Seguinot-Barbosa J (1983) Coastal Modification and Land Transformation in the San Juan Bay Area: Puerto Rico.

Seguinot Barbosa J (1996) La ecologia urbana de San Juan. Una interpretación geográfica-social. In: Anales de Geografía de la Universidad Complutense. p 161

Sherman RE, Fahey TJ, Howarth RW (1998) Soil-plant interactions in a neotropical mangrove forest: iron, phosphorus and sulfur dynamics. Oecologia 115:553-563

Stephenson AG (2016) Harmonic Analysis of Tides Using TideHarmonics

Sutula M, Day JW, Cable J, Rudnick D (2001) Hydrological and nutrient budgets of freshwater and estuarine wetlands of Taylor Slough in Southern Everglades, Florida (USA). Biogeochemistry 56:287-310

Tam NFY, Wong YS (1998) Variations of soil nutrient and organic matter content in a subtropical mangrove ecosystem. Water Air Soil Pollut 103:245-261

Temple Lang D (2014) RJSONIO: Serialize R objects to JSON, JavaScript Object Notation 
mangrove wetland area change with remote sensing. China Ocean Eng 22:347-358

Toth E, Brath A, Montanari A (2000) Comparison of short-term rainfall prediction models for real-time flood forecasting. J Hydrol 239:132-147

354 Turner R (2017) deldir: Delaunay Triangulation and Dirichlet (Voronoi) Tessellation

355

Twilley RR, Chen R (1998) A water budget and hydrology model of a basin mangrove forest in Rookery Bay, Florida. Mar Freshw Res 49:309-323

U.S. Census Bureau (2010) Total population at census block level

U.S. Census Bureau (2015) 2015 TIGER/Line Shapefiles roads

Ulrich J (2017) TTR: Technical Trading Rules

United States Army Corps of Engineers (2015) San Juan harbor, Puerto Rico, submerged aquatic vegetation mitigation environmental assessment

United States Census Bureau (2016) US Census QuickFacts. https://www.census.gov/quickfacts/fact/table/US/HSG030210

USACE (1987) A study to determine the feasability of providing flood control on the rio de la plata in Toa Baja - Dorado Area, Puerto Rico. Jacksonville

USGS (2011) Hydrology and water quality of the Levittown lake, Toa Baja, Puerto Rico

Webb RMT, Gómez-Gómez F (1998) Synoptic survey of water quality and bottom sediments, San Juan Bay estuary system, Puerto Rico, December 1994-July 1995. US Department of the Interior, US Geological Survey

Wickham H (2009) ggplot2: Elegant Graphics for Data Analysis. Springer-Verlag, New York, NY

Williams JJ, Esteves LS (2017) Guidance on Setup, Calibration, and Validation of Hydrodynamic, Wave, and Sediment Models for Shelf Seas and Estuaries. Adv Civ Eng 2017:

Wolanski E, Mazda Y, Ridd P (1993) Mangrove hydrodynamics. Trop mangrove Ecosyst 43-62

Wong YS, Tam NFY, Lan CY (1997) Mangrove wetlands as wastewater treatment facility: A field trial. In: Wong Y-S, Tam N-Y (eds) Hydrobiologia. Springer Netherlands, Belgium, pp 49-59

Yan J, Valdez EA, Trivedi PK, et al (2011) R: A Language and Environment for Statistical Computing. R Foundation for Statistical Computing, Vienna, Austria

Zeilis A, Grothendieck G (2005) zoo: S3 Infrastructure for Regular and Irregular Time Series. J Stat Softw 14:1-27 